\title{
Algeria
}

\section{The Dwellers in the Garden of Allah}

\author{
By A. MacCallum Scott, M.A., M.P. \\ Author of "Barbary : The Romance of the Nearest East"
}

\begin{abstract}
A
LGIERS, say the Arabs, is like a diamond set in emeralds. The terraces of its white walls and flat roofs rise in a pyramid up the steep hillside, that looks eastward over the far-stretching bay to the distant violet and snowpatched peaks of the Diurdiura Mountains. It is embosomed in the vivid greenery of palms and orange and lemon groves, from the midst of which, like outlying
\end{abstract} pearls, peep the domes and Moorish arches of palaces and villas.

This is the sight that meets one approaching from the sea. A few fishing boats, dotted over the surface of the bay, with iong, raking, lateen sails, recall vividly the swift hawk-like pirate craft which used to swoop out from this lair, and earned for Algiers the name of the Scourge of Christendom. But it is in Europe that one lands. The harbour itself, with its trim goods sheds and custom house, is of Europe.

The promenade, which runs like a high terrace above the harbour, with its long, regular $f$ açade of tall houses, is of the type that you may see in every capital in Europe. And from it the visitor drives over a well-paved street, along which electric cars are running, through a boulevard which might be Paris.

All around are ladies in Paris costumes and dapper business men. In the arcades on either side luxurious shops display a wealth of beautiful ware. In front of the cafés chairs and little marble tables

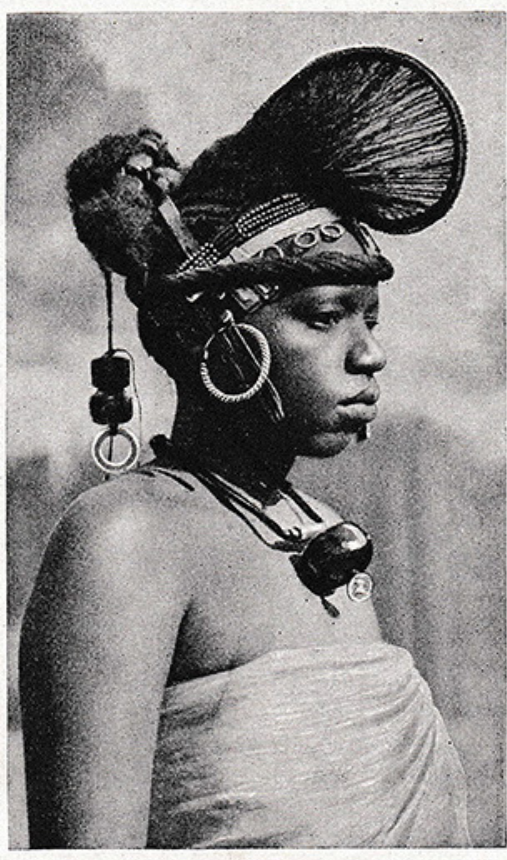

PREPARED FOR THE SLAVE TRADE Many a rich Moslem of Algeria dodges the law forbidding traffic in slaves by buying this kind of black girl, first for his harem, and then, as she grows old, for household work

Photo, Crtte invade the pavement, and comfortable citizens sit sipping their coffee. Surely France has conquered. This is not Africa, but New France.

But turn up one of the narrow passages that lead off this Parisian boulevard. Immediately we are in another world. It is as if we had been transported by enchantment to the Bagdad of Haroun alRaschid of the "Arabian Nights." We are lost in the labyrinthine galleries of a human hive. The mystery, the glamour of the East surrounds us. Fantastic figures stream past, unheedingly jostling us, living their own lives,pursuing 
ALGERIA \& THE ALGERIANS

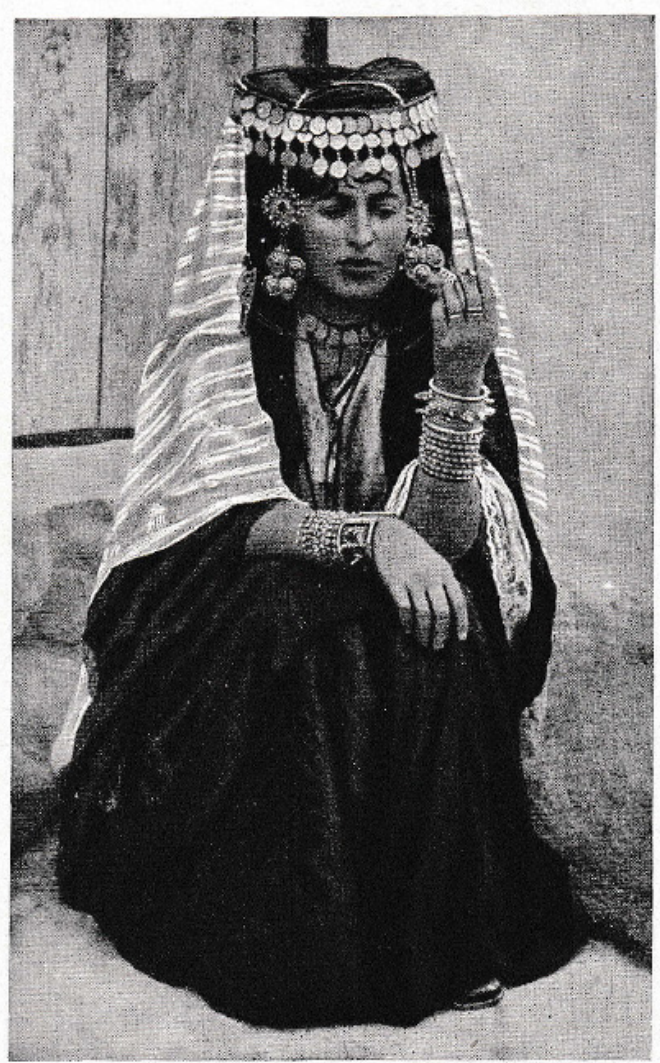

FAIR TYPE OF DESERT ENCHANTRESS

Being bred from negress captives by nomad Shawia mountaineers, the Ouled Nail tribe often produces fine Berber-like offspring, such as this highly-prized beauty, decorated in Berber silverwork, golden coins, and many rich bracelets

$$
\text { Photo, Crite }
$$

their inscrutable occupations, oblivious of the call of Western civilization a hundred yards away.

Closely-veiled women, shrouded in spotless white, flit past like shadows. Others, less scrupulously veiled, loll about in doorways invitingly open. Arabs in turbans and robes of purple and fine linen stalk past with the stately stride their ancestors acquired in the Desert. Moors, with gorgeously embroidered waistcoats and voluminous trousers gathered in at the ankle, long-haired Jews, Kabyle workmen, Mozabite traders, Biskra water-carriers and scavengers, and broadly-smiling negroes of all shades complete the throng.

The houses in the native quarter of Algiers are built on a steep hillside, and seem to rise on each other's shoulders, not in regular terraces, but huddled in accordance with all the irregularities of the site. The tiny passages between them mount the hillside like flights of stairs. They are quite impervious to horse or even mule traffic, but strings of little donkeys, laden with panniers, clamber nimbly up them. The houses overhang perilously on either side, the upper storeys being supported by long buttressing beams springing out at a sharp angle from the wall.

The shops of the native quarter have little in common with the magnificent emporiums in the French quarter. They are mere booths. Under the Turks it was dangerous for any trader to show signs of prosperity, and the air of secrecy and mystery which broods over the town is due to the instinct to conceal wealth and worldly possessions.

A vast business may be conducted from a dark little cave, which seems a mere hole in the wall. The shopkeepers are a race of troglodytes. At the tailor's there is no room for trying on a garment in the shop. The customer stands out in the middle of the street, and the vendor, with many 


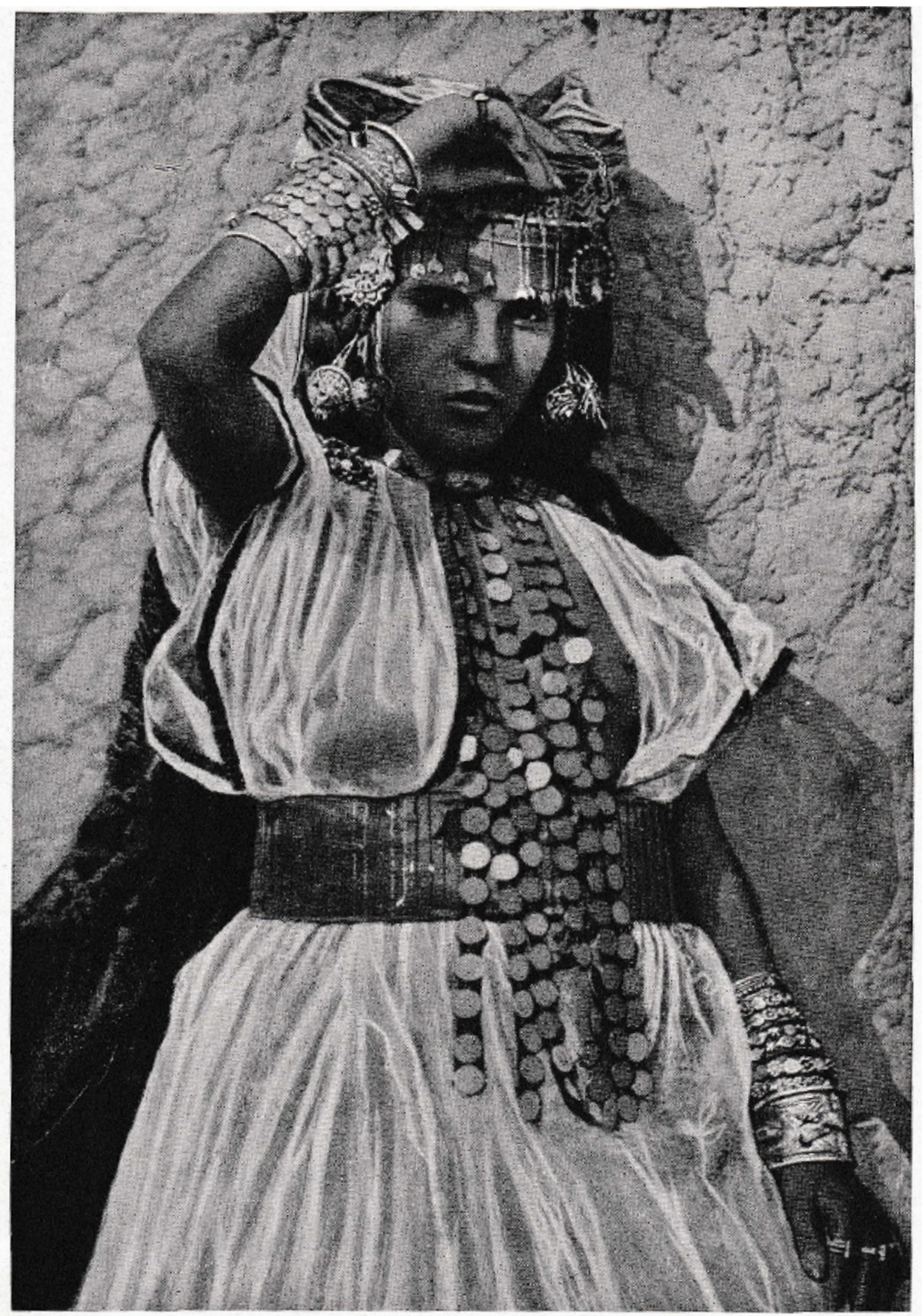

\section{A DANGEROUS BEAUTY IN SULLEN MOOD}

She has stood, until weary of attracting attention, by a wall in Biskra, this geisha of the Sahara, with her hard-won dowry of gold and silver adorning her person. She can sing Arab love-songs, play flute, hautboy, and zither, and dance more seductively than girls of any other tribe. Her zkill in making cigarettes and coffee is tamous, and all her charms and acoomplishments are for hire Photo, crets 


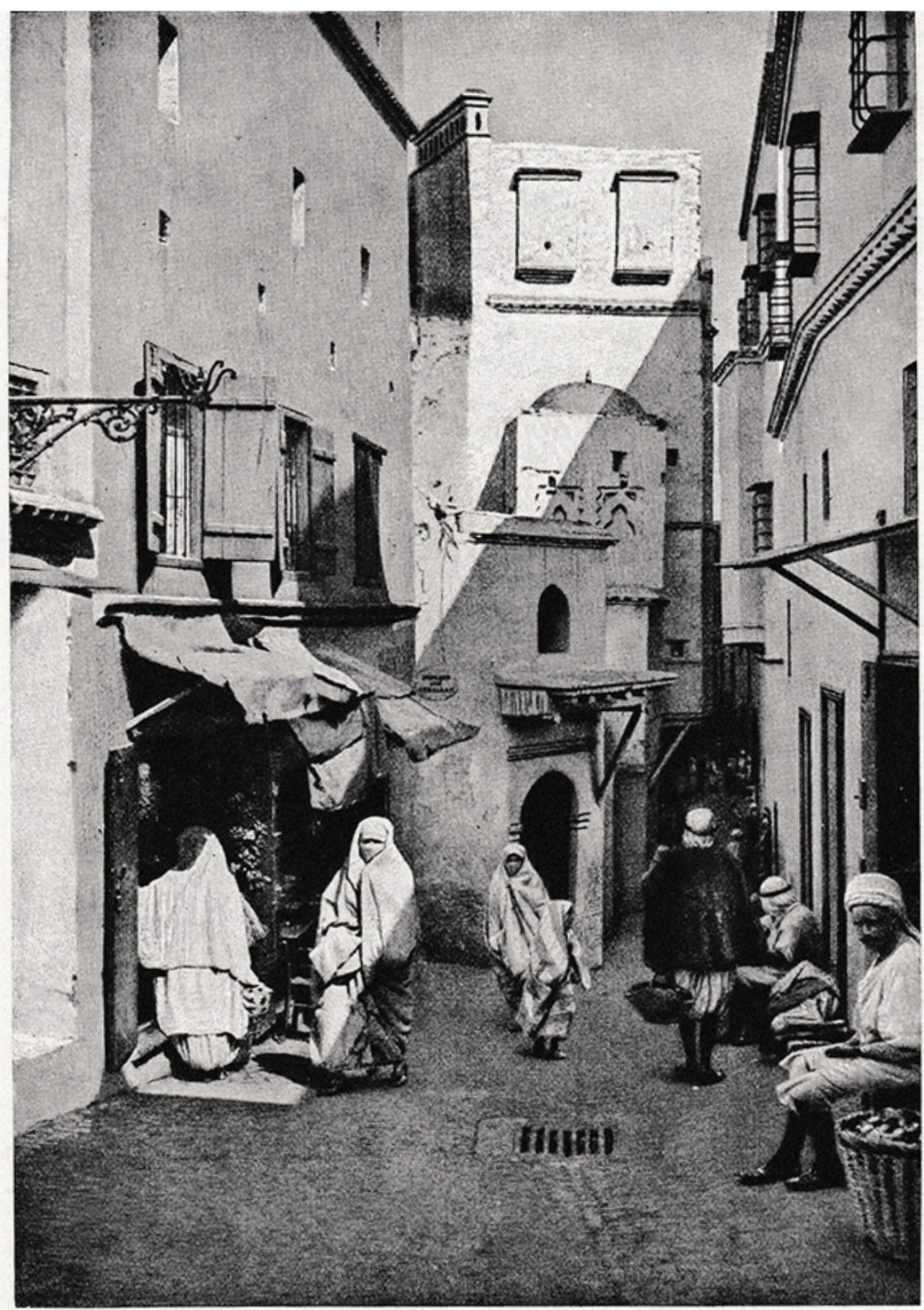

PICTURESQUE NOOK IN THE STREET OF THE ROYAL KASBAH

Above the white cascade of houses, mosques, and palaces, which is cliff-built Algiers, rises the Kasbah, the Moorish castle of the piratic old Deys. It is now a French barracks, but native life still centres, in a fine play of colour framed and dappled with white, by the old seat of power which serves as a grim reminder of the days when warfare and strife reigned supreme Photo, Critt 


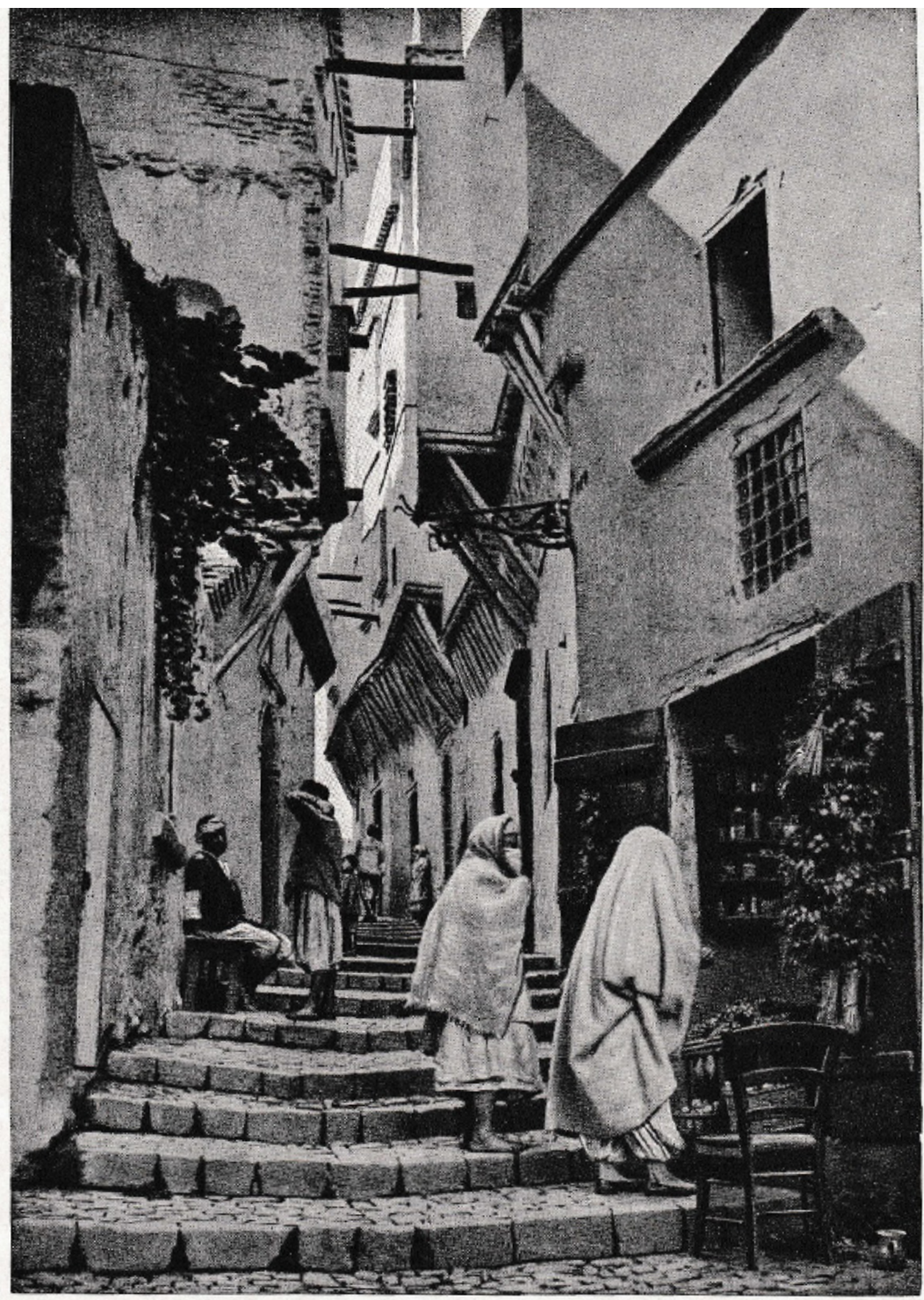

WOMEN OF THE HAREM SHOPPING IN CLIMBING ALGIERS

Many Moslem Ladies are famous tor the perfection of theit figures. Centuries of sucocsstu prracy enabled the leading Algerians to capture or purchase tens of thousands of European and Georgian girls of beauty, but in their outdoor dress, designed to conceal all their charms, the belles of Algiers resemble white toads standing on their hind teet

Phow Geotr 


\section{BibliotecA}

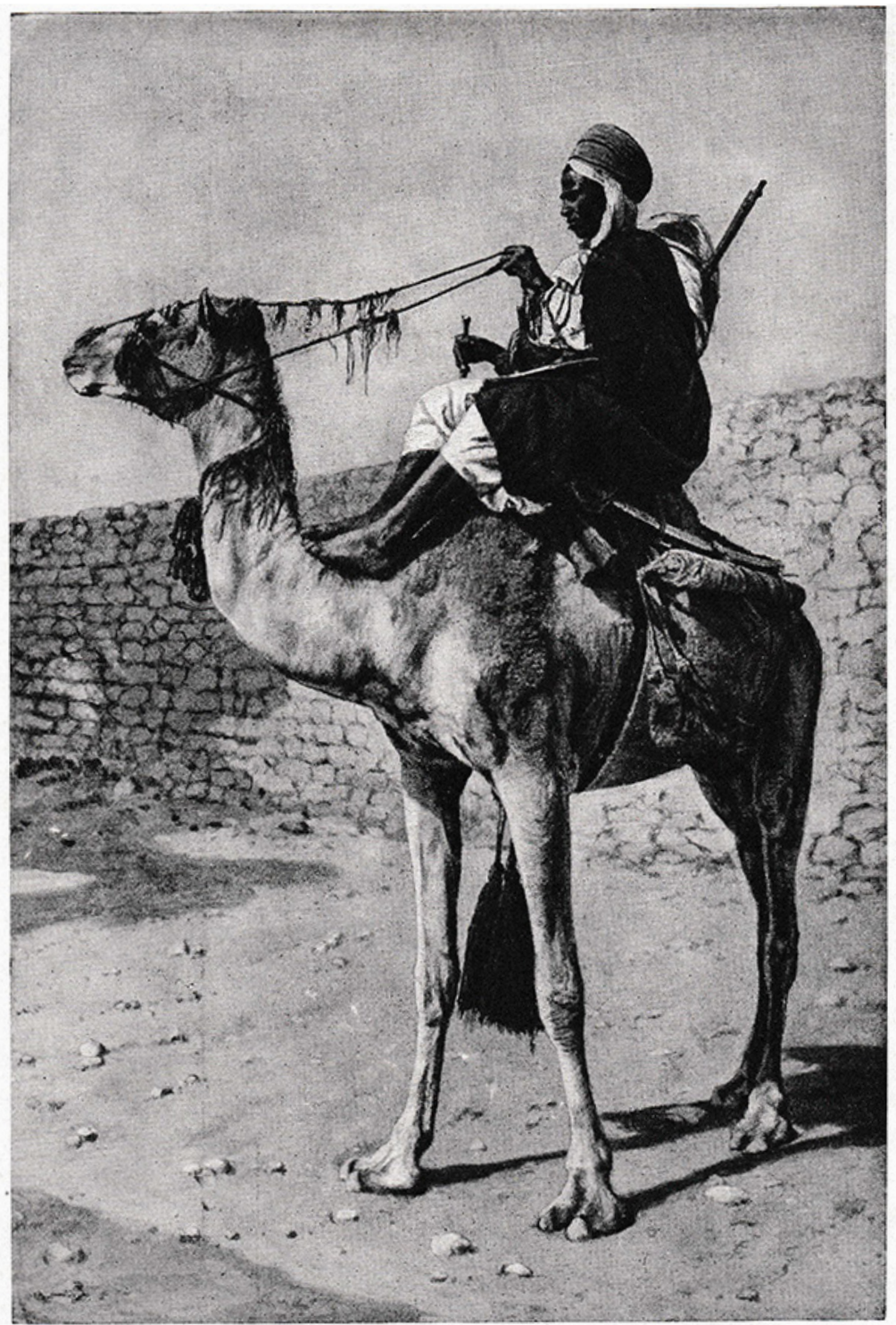

HALF-BREED SPAHI CAVALRYMAN OF THE SAHARA

As the coastland sharpshooters of Algeria could not stand the fighting life in the southern Desert a camel corps was formed of the Berber-negro stock of the Desert oases. Born and bred between the furnace sun and oven-hot sand, these men who were in the old days coloured serfs of the white slave-raiding Tuaregs have mastered their old masters 


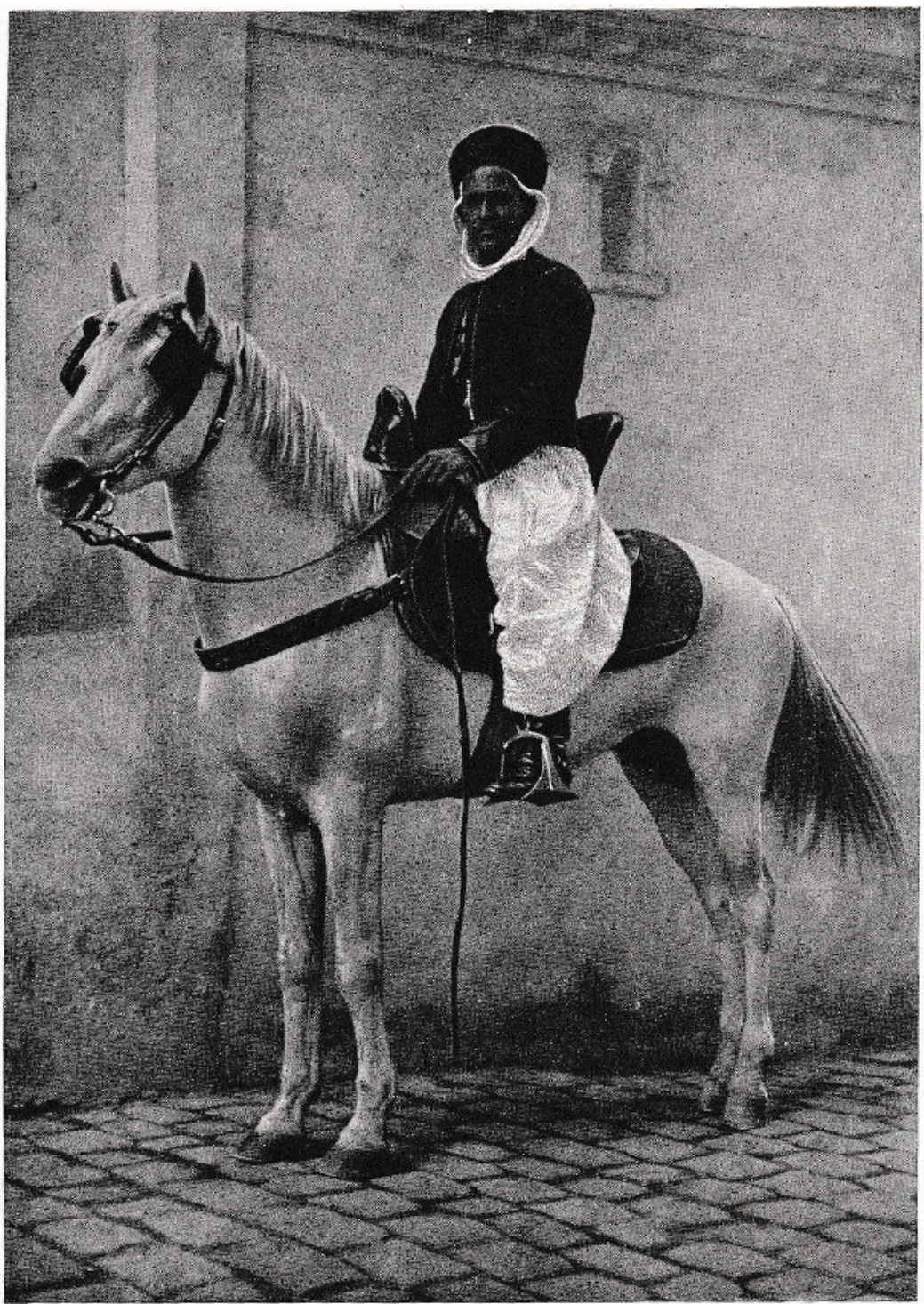

ONE OF THE BEST AND MOST FEARLESS HORSEMEN IN THE WORLD

When the white-skinned Berber of the Desert, with a face of the European kind, is turned into a loyal Spahi cavalryman it is hard to find a better soldier. Over bis own sands, on a mount of his choosing, he can outride or wear down even the Arab. With men of this sort, his famous Numidian cavalry, Hannibal broke the Roman legions in the Punic Wars Photo, Donald McLoish 
ALGERIA \& THE ALGERIANS

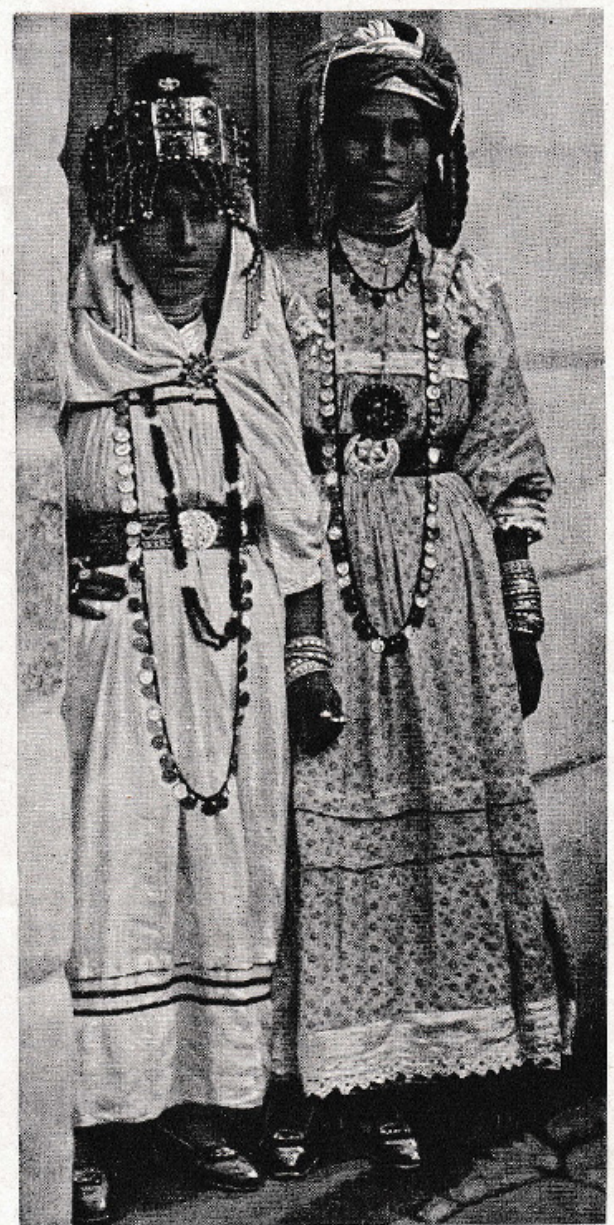

DANCING SIRENS OF THE OULED NAIIL

Born in the Ziban oases, south of Biskra, these girls wander from Tripoli to Tangier, and gaining, by dancing and love affairs, gold coins enough to make a breast-plate, they return and marry, in high honour, their own tribesmen

$$
\text { Photo. T. C. Hvam }
$$

exclamations of admuation, fits it on, giving it a pat here and a tug there. The neighbours join in with hints and suggestions, and the traffic is held up till the bargain is completed. Allàh did not make hurry!
The barber and the dentist and the protessional letter: writer pursue their avocations on the pavement. At the entrance of many of the caves sits the craftsman plying his hereditary craftstitching, cobbling, soldering tin, or mending musical instruments. The air is heavy with the indescribable odour of the East-a compound of spices, aromatics, cookery, and dust-heaps.

The native coffee-house café maure, is merely a bare room with a few benches about it, and a stove at the end. The frequenters squat on the benches or on the floor, or on straw mats out on the cobble stones in front of it. The coffee is thick and black and sweet as syrup, and they sip it from little cups, with long intervals for contemplation. Some are intent on garnes of cards, dominoes, or chess.

$\mathrm{U}_{\mathrm{p}}$ on the wider space, near the Kasbah, the citadel and palace of the former Deys of Algiers, there is a small market square, where fruit and cast-off clothing are displayed. Here may be seen one of the oldest and most familiar sights of the East. In a corner a large group are gathered round an aged, half-blind Arab storyteller or orator, who sits cross-legged and tells his tale with great unction and dramatic effect.

The prosperous merchant drops his newspaper and squats down in the circle. What is it that holds the audience in such rapt attention? Does he tell of the days of the Christian slaves? Is it doctrine or politics, or history, or mere idle and amusing tales ? Do the Thousand and One Nights thus live again? The 


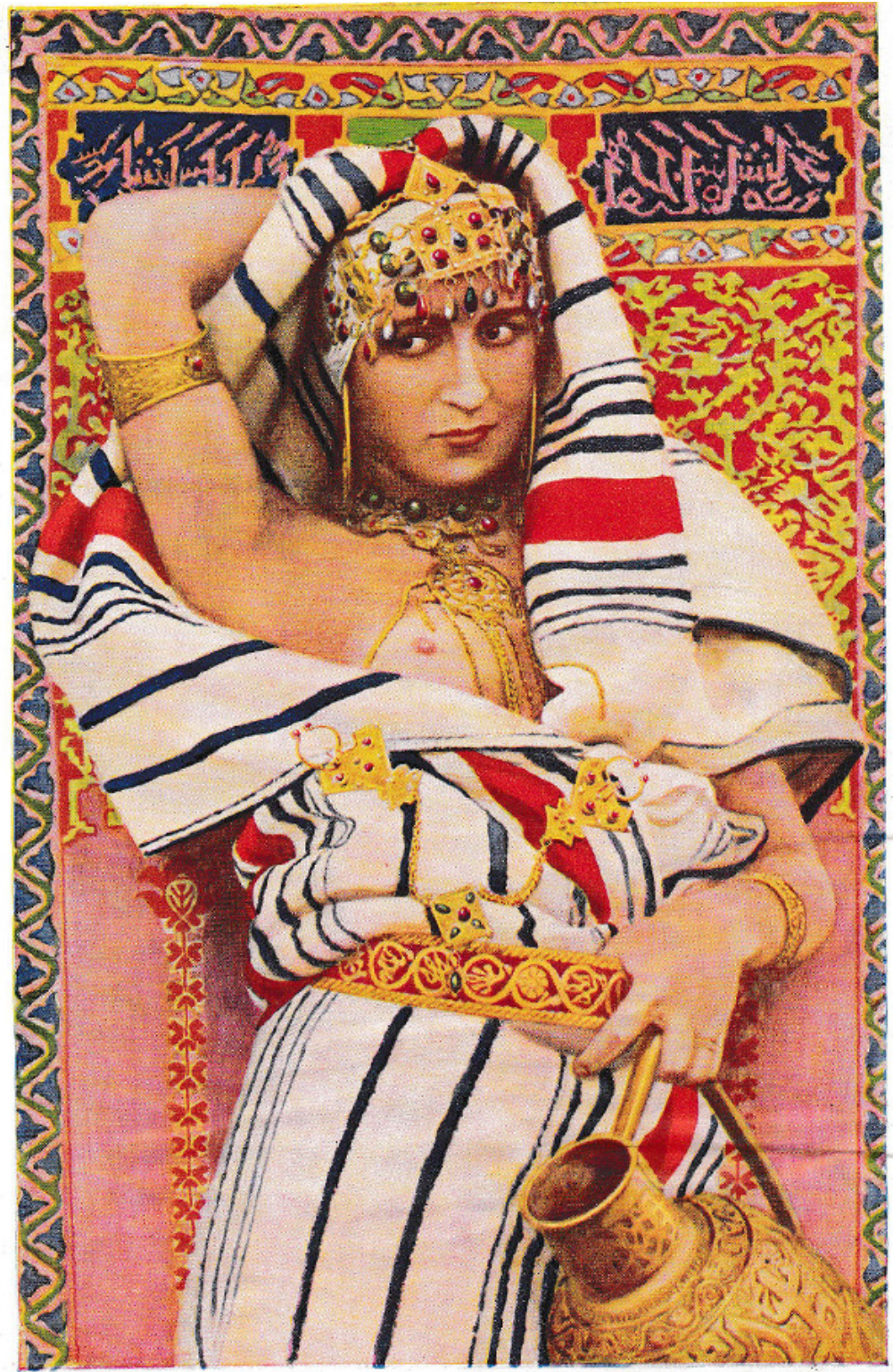

ALGERIA: A BEJEWELLED BEAUTY OF THE KABYLES 


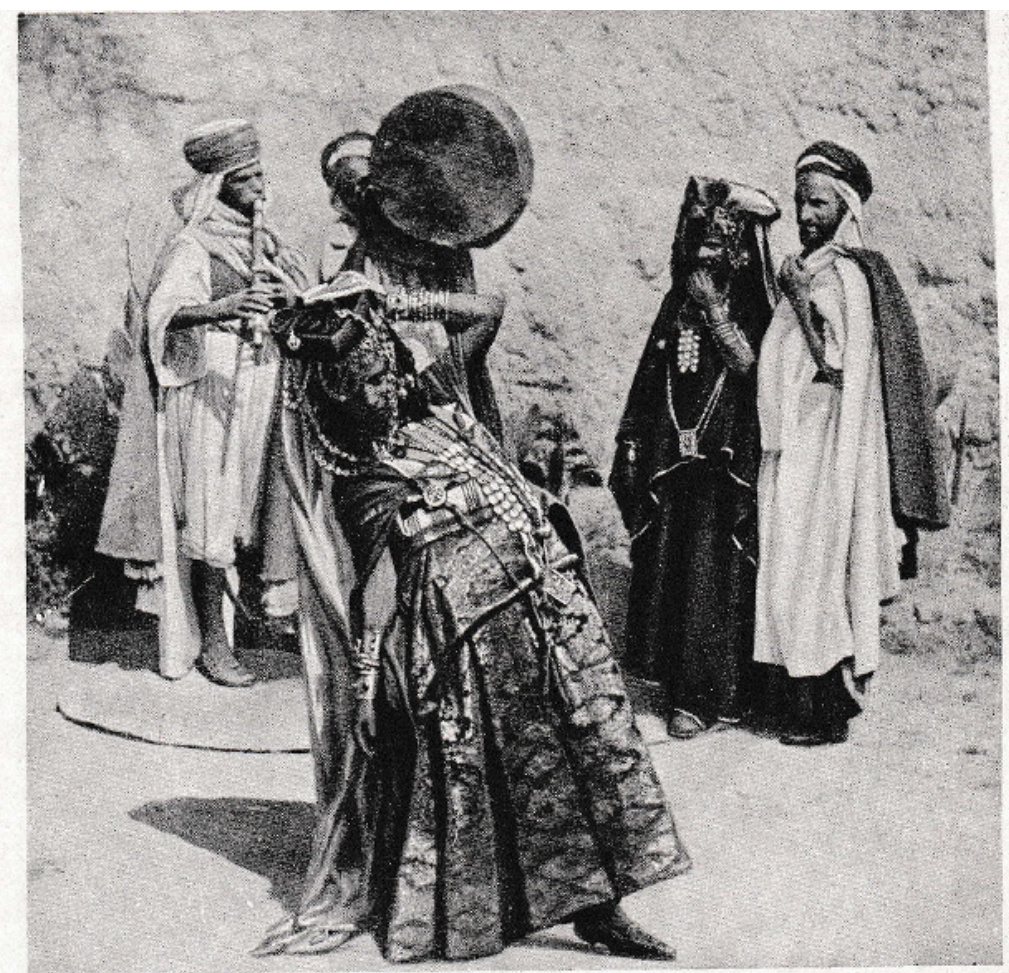

OULED NAIIL BEGINNING HER STRANGE DANCE OF PASSION

Shameless and attractive, and as learned in all the arts of love as Cleopatra, the dancing-girl from the Sahara will perform in the open street, in the pasha's harem, or in the native café. This dancer is beginning her career, and is only about thirteen years of age, for she wears few golden coins Photo, Crats

natives are largely illiterate, and this is their newspaper, their political pamphlet, ther novel. So the ancient memories and traditions of the race are kept alive.

The Moorish houses are singularly non-European. They offer nothing but blank, precipitous, and sometimes overhanging walls to the gaze of the passer-by. There is no external decoration. There are no windows. only a few narrow grated loopholes. The door is the door of a fortress or a prison. And, mdeed these houses of mystery are both prison and tortress, a prison to the veiled women. and a fortress against European influence. It is only the back of the house that we see from without: the decorative façade is all turned within Like a shell, it is rough without, but within are all the exquisite rainbow tints of mother-of-pearl.

In the centre of all is a square court paved with marble or tiles, with a fountain rippling continuously, and perhaps an orange tree, the dark green of the foliage lit up by golden globes. Right round the court runs an arcade of Moorish arches, supported by delicate pillars. From this the public rooms and offices open. An upper gallery sumilarly arcaded, and with a wooden balustrade of intricate 


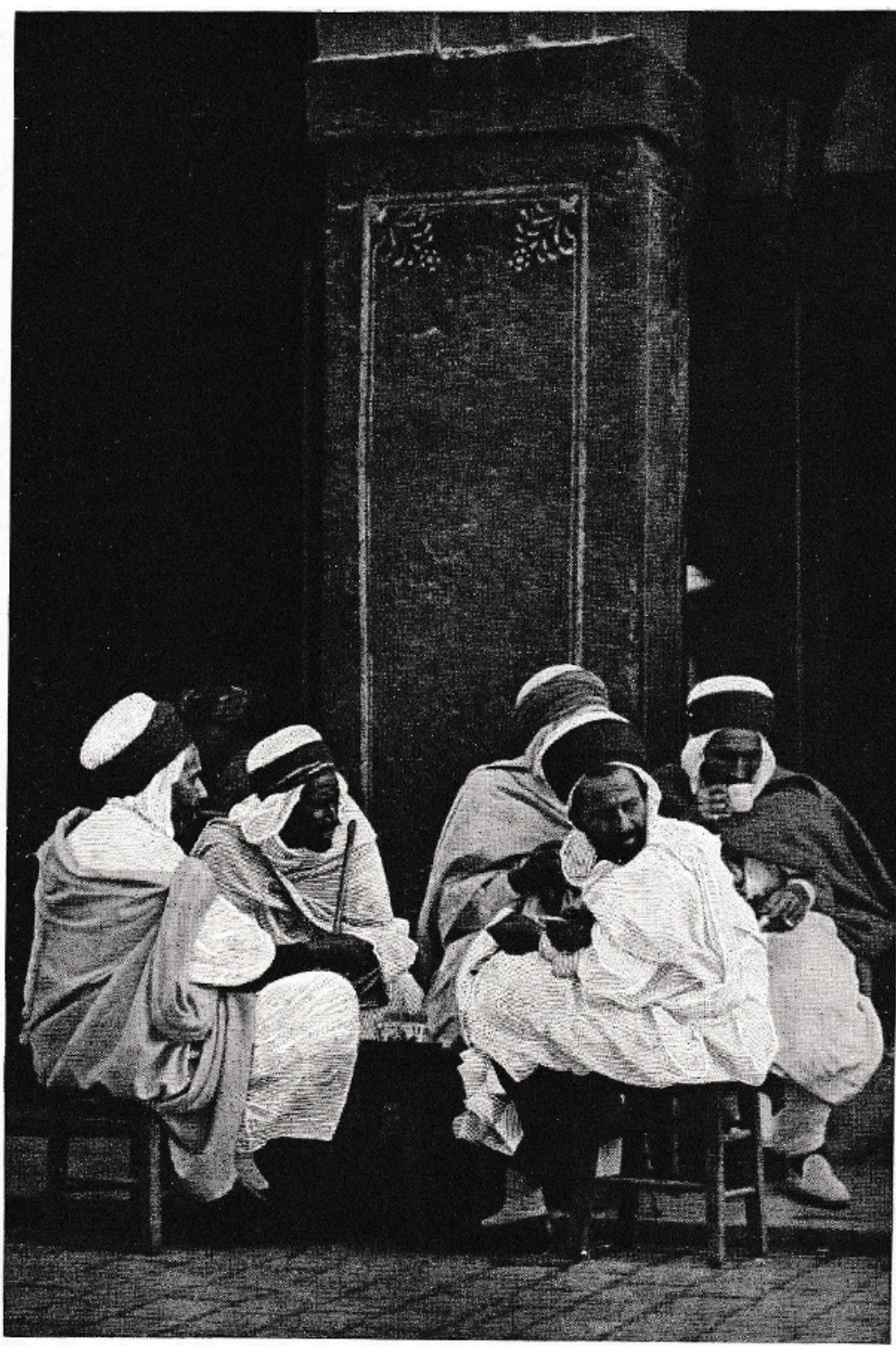

THE SUGARY LURE OF THE MOORISH COFFEE TAVERN

Founded in its present form by Moorish fugitives from Spain, the coffee tavern has spread from Algiers to the Sahara. It attracts and holds loafers of all classes, usually remarkable by their obesity. Over a charcoal fire the coffee decoction is thrice whipped of the boil and sugared into a thickish syrup Pho: Donaid McLeish 
ALGERIA \& THE ALGERIANS

arabesque pattern, also runs right round the square. From it open the private apartments. The walls, where visible, are generally encrusted with lustrous and brilliantly-coloured tiles.

As the houses rise in terraces up the steep hillside, each flat roof affords a view of the harbour and the bay, and the more distant prospect of the Mediterranean or the Djurdịura Mountains. There is no busy street scene to view, for the tortuous alleys burrow, like tunnels or galleries in an ants' nest, far below the overhanging roofs. Here is the woman's realm. Here is all the world they know. From here they listen to the distant hum of traffic and watch the great ships come and go in a world that is beyond their ken.

In Turkish times the roofs were strictly reserved for the women. They took the air here. they enjoyed the freshness of the evening breeze, they climbed over the parapets, and passing from roof to roof visited their female friends. The system lent itself to intrigue, for nothing was easier than for the bold lover to disguise himself in female attire and to thread his way through the maze of roofs, under the guidance of some old hag bribed by mistress and lover alike

Many a time he found the adven. ture as perilous as Leander found the crossing of the Hellespont. The traditional literature of the people is full of romantic stories of such adventures of the kind so well known to Western readers through the "Arabian Nights" tales. Moreover, this custom throws a

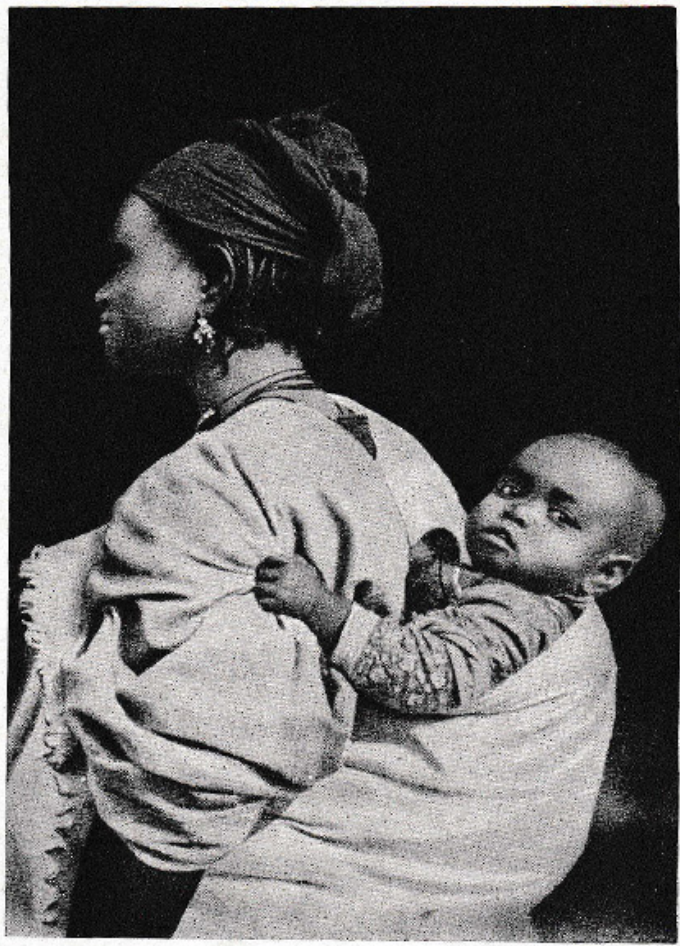

TAR-BRUSHES THAT BLACKEN OLD BARBARY This young negro mother and her piccaninny are weapons of destiny. Negress slaves in the harem have changed the former verning Arab stock into weak-minded blackamoors. The purePhoto, Crete

somewhat interesting light upon the Bible story of David and Bathsheba.

The veil and all that it implies with regard to the seclusion of women is one of the most powerful of social institutions, and it is one of the most formidable barriers between the two races in North Africa. It is not merely an incidental custom or freak of fashion, like a fez or a bowler hat.

It is the symbol of a whole system of social life and ethics, utterly alien to us. It is futile to measure it by our European standards and to dismiss it as a badge of sex inferiority and the degradation of family life; even 


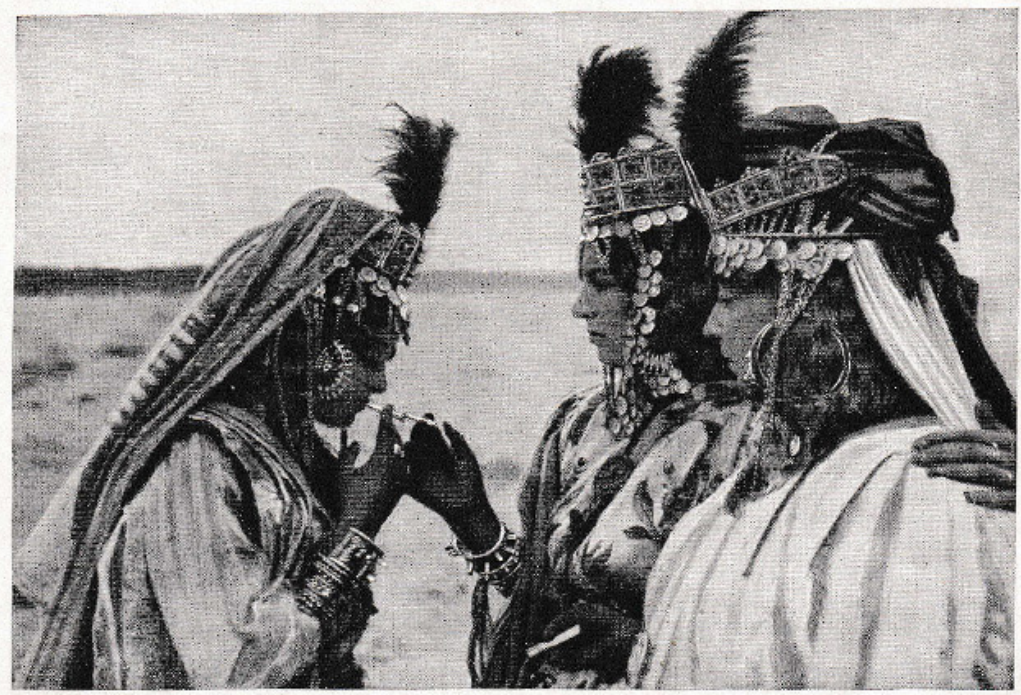

MISTRESSES IN ALL ARTS OF FASCINATING MEN

Mulatto girls of the Ouled Nalls are works of art. Their hair and eyebrows are dyed blue-black. Their carmine lips and red nails are, like their picturesque coifs and rich and varied jewelry, additions to the tar-brush tint of skin. The cigarette is but an item in their sophisticated charms

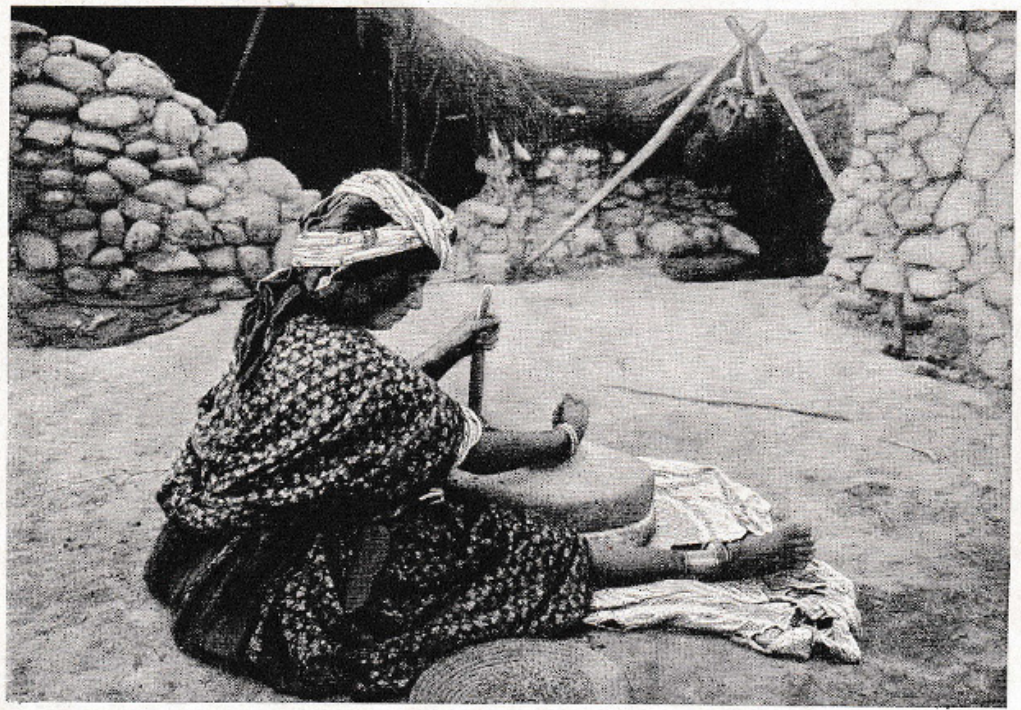

NOMAD MAID OF THE MILL PREPARING COUSCOUS

She pours the barley through a hole in the upper stone, which she turns by means of the stick. The grain is cooked with mutton, honey, and a variety of things to form the national dish, couscous Photos, A. Bowrault 


\section{ALGERIA \& THE ALGERIANS}

so, an Arab might talk about our social customs, if they were to be measured by his standards.

Just as Japan has its Yoshiwara, the resort of the geishas, so Algiers has its Kattaroudjie. An even more remarkable street of this character exists in the Desert town of Biskra, the street of the Ouled Nails. The Ouled Naïls are a tribe in the Aurès Mountains, whose women are the hereditary geisha of the Desert. They come down to the towns to earn their dowry and return to resume the veil, and settle down to married infe in their mountain homes.

In this quarter may be seen the Moorish dances, the more exotic danse du ventre, and the so-called Andalusian fandango. This latter orgy, as the name indicates, is more in accordance with European conceptions, a dance of mænads and corybantes, a display of violent motion and tossing limbs. The others are as alien as the camel, the cactus, and the palm tree. They are full of the subtle seduction of the East They ase like an opium eater's dream. The difference is that between drugs and wine.

Most alien to our ears of a!l the sounds of Algiers is the native music. Throughout Europe music is an international language. It makes its direct appeal to the emotions independently of all differences of language race, custom, and religion. But here in Africa even the music is in a different idiom. It is something more primitive than the immemorial civilizations of Asia which still hold North Africa in their gripsomething that springs out of the savage black heart of Africa itself, beyond the Desert.

The basis of this weird music would seem to be the tom-tom, or African drum. The range of stringed or flute music is limited to a few notes which are repeated over and over again. In our ears this music is almost the negation of music-

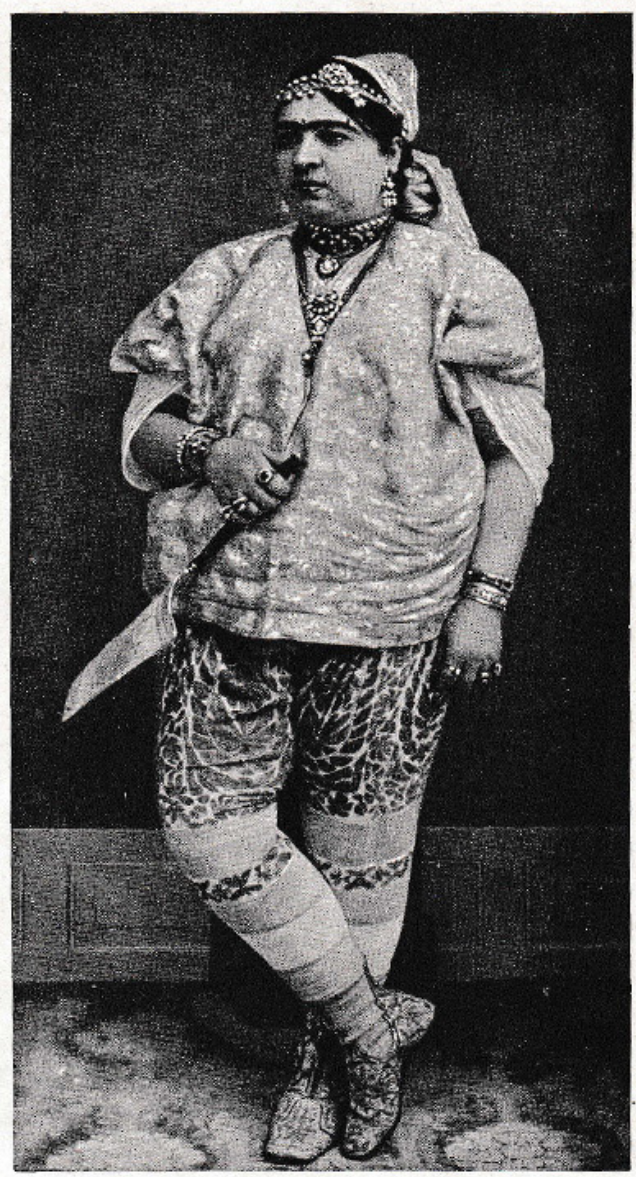

TROUSERED JEWESS OF ALGIERS

The women of the richest race in French Africa are tamous for their voluptuous figures. Made up in harem fashion, with gay Persian-like trousers, fly-flappers, quaint puttees, painted eyebrows and lips, they reek of beavy scents 


\section{ALGERIA \& THE ALGERIANS}

dull, uninteresting, crude, monotonous. In fact, it is not tonic, but rhythmic. But it exercises a powerful spell upon the natives. Packed audiences will sit and listen in ecstasy to this thrumming and drumming. The atmosphere vibrates with the reiteration of rhythmic beat, and the listeners are swayed by some hypnotic influence.

Throughout Algiers the mosques are freely open to Christian visitors, provided they remove their shoes or pull over them the large slippers which are supplied in the vestibule. Within these sanctuaries of Allah one can still feel the living force of the great Prophet of the Desert, who established a religion which has more followers than Christianity to-day. Mahomet was a religious reformer. A fierce monotheism was the essence of his creed. He suppressed polytheism and idolatry, and the superstitious abominations which enslaved his people. He made his Desert tribe the rulers of a world as great as that of Rome, the masters of a civilization that preserved science and learning when the lamp of Rome was flickering.

The Church he founded is the greatest and most successful missionary church in pagan Africa to-day. Millions of men throughout the world still regard his lightest word as law. And within the cloistered gloom of these Mahomedan temples even the northern Protestant, noting the austere simplicity of the mechanical

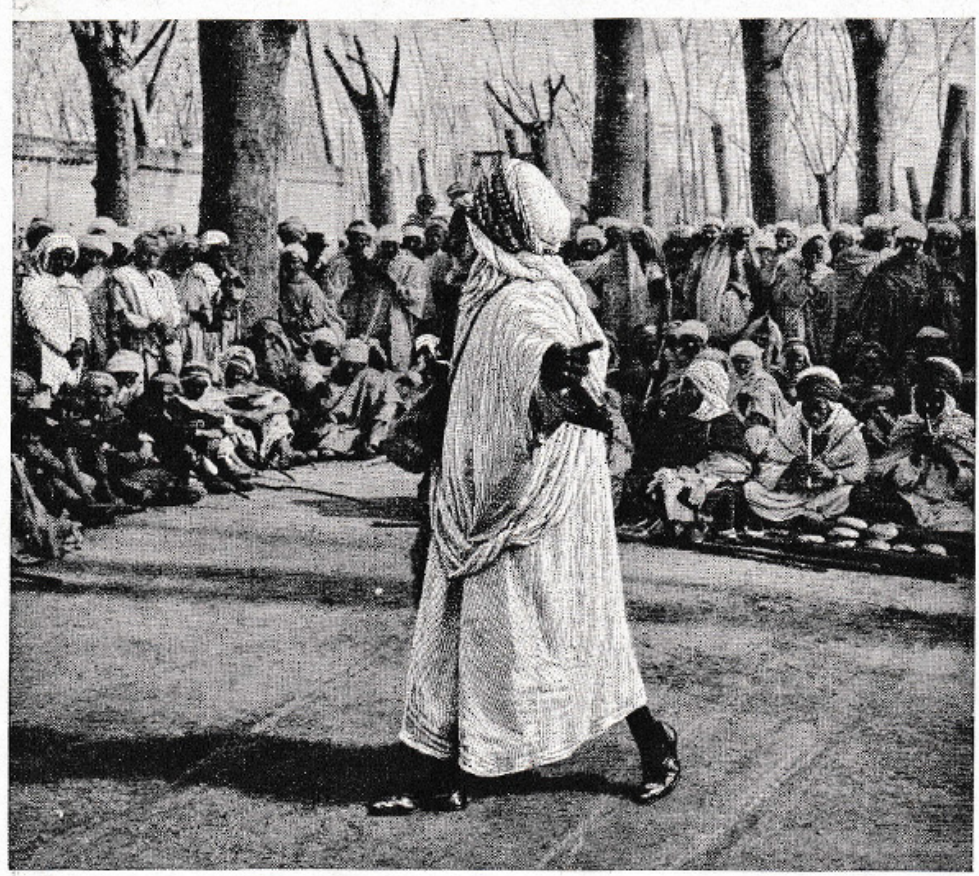

ALGERIAN ORATORY DRAWS A CROWD TO THE KASBAH SQUARE

The little market-place at the top of Algiers is the sounding-board of the native mind. Round it a crowd will rank itself to listen to such a dramatic speaker as this. News, old tales, or political speeches will usually hold an audience that is particularly eager because it is largely illiterate Photo. Mr. Hewry Porritt 


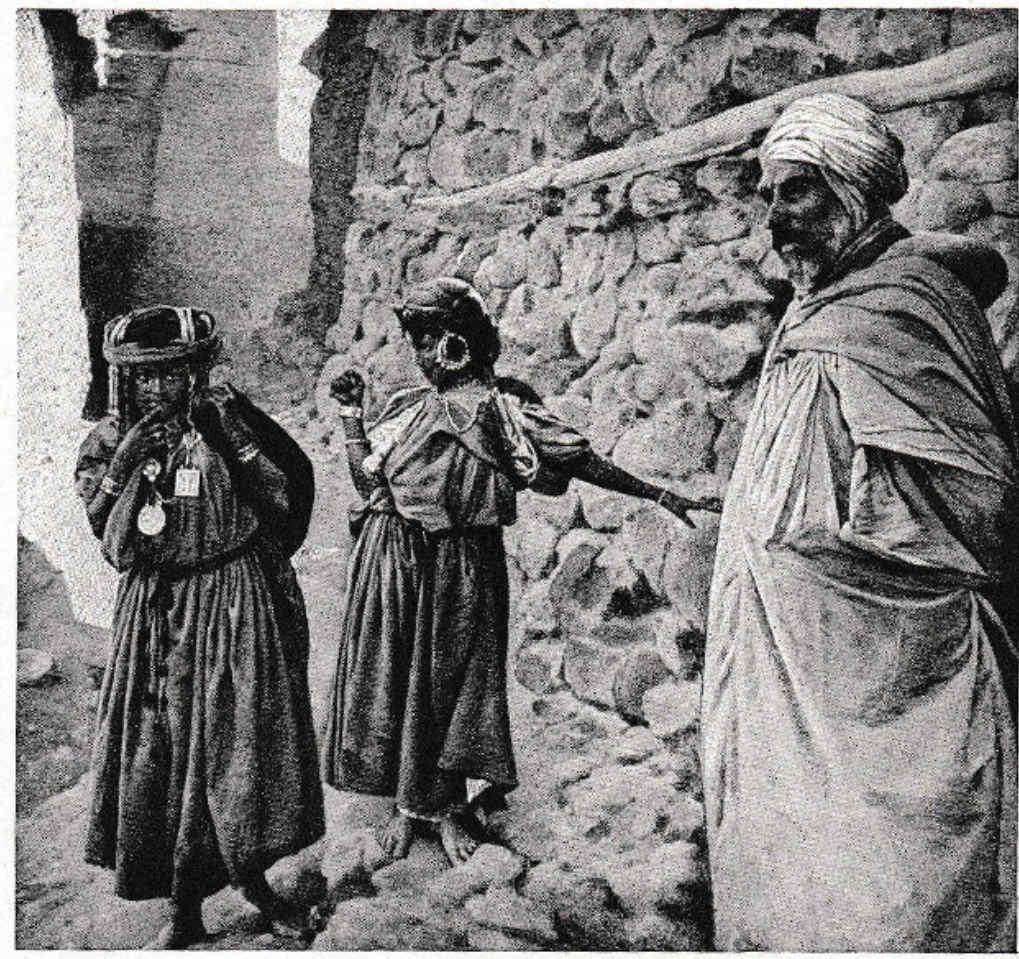

PRETTY SHAWIA WOMEN IN THE MOUNTAIN TOWN OF MENAA

Unveiled and jingling with jewelry as they walk, the fair-haired, blue-eyed Shawia women of the fighting Aurès villages darken their skin with pigment. They are proud, free, hardworking Berber beauties, who are saved by ancient pagan rights from the close restrictions of the ordinary Moslem harem. Here they are seen in working dress. Festive attire is a blaze of colour

aids to piety, cannot fail to be $1 \mathrm{~m}$ pressed by the air of intense adoration and worship which pervades the place.

Religion is the supreme expression of the difference between Europe and Africa. Mahomedanism has laid its spell over all the land. It completely obliterated the great African Church of Cyprian, Tertullian, and Augustine through which Christianity first became the religion of Europe. It inundated Spain, and its waves beat against the barrier of the Pyrenees, but it ebbed back to Africa again.

There it remains settled, supreme, unmoved in its empire over men's minds, though the sceptre of temporal power has slipped from its grasp. In the observance of religious rites the Mahomedan is surpassed by the professors of no other religious faith, and his religion colours his whole outlook upon life, his hopes and fears for the future, his social and domestic habits, his morality. The real distinction is this-that modern Christianity embodies the ethics of the temperate zone, while Mahomedanism embodies the ethics of the heat belt.

France has not been unduly tender with regard to Mahomedan susceptibilities. The civil rights of the natives are scrupulously safeguarded by legislation and administration. The people are free to worship in 


\section{ALGERIA \& THE ALGERIANS}

accordance with the tenets of their own faith, provided they do not interfere with the exercise of similar rights by others. But there must be no doubt as to who is master in civil affairs. The Republic which broke the power of the Church of Rome in France will not submit to any dictation or presumption on the part of the Church of Mahomet in Algeria. The fierce, conquering creed of Mahomet must learn to tolerate rivals and to restrain its aversion from the "dog of an unbeliever." The cathedral was formerly a mosque, and many other mosques have been

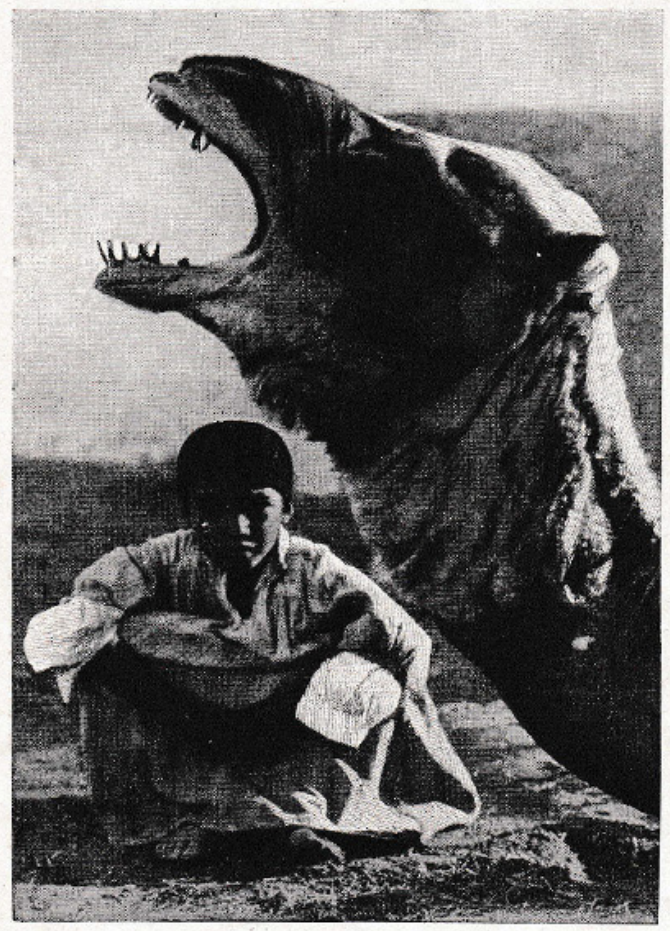

CAMEL BOY AND HIS HUMPY DARLING Lovingly does the Saharan speak of his "mehari," On this tall, fast-trotting dromedary the Tuareg boy will cover fifty miles. So shaped is he from childhood to his racing camel that he looks and feels awkward when dismounted Pkclo, Crite diverted to secular uses. At a prominent view-point outside Algiers a cross has been erected with the inscription: "In hoc signo vinces."

But, so far, the Cross does not prevail. The Government of the Republic is not a religious institution, much less a proselytising one. A strict impartiality is all that can be expected from it. Great efforts have been made in missionaty work, but they have produced little result. The greatest efforts were those made by Cardinal Lavigerie, the archbishop of Carthage, a man whose magnetic character and great energy entitle him to be ranked among the great figures in African history. Among his manifold labours he founded an order of priests, the White Fathers, consecrated to the work of the conversion of Africa. They received a special training and they went out into the Desert and penetrated remote parts of Central Africa dressed as Arabs and living the life of the natives.

Their labours did much to end the slave trade, and during a great famine they rescued many children. The White Fathers still work and pray and sacrifice their lives to the conversion of Africa. But the seed they have sown has not yet grown and fructified. The spiritual dominion of Mahomedanism is absolute and unshaken.

The Great Atlas range runs along the edge of the Desert about two or three hundred miles from the Mediterranean. Along the coast, almost parallel to it, but converging to meet in Tunisia, runs the Little Atlas range. 


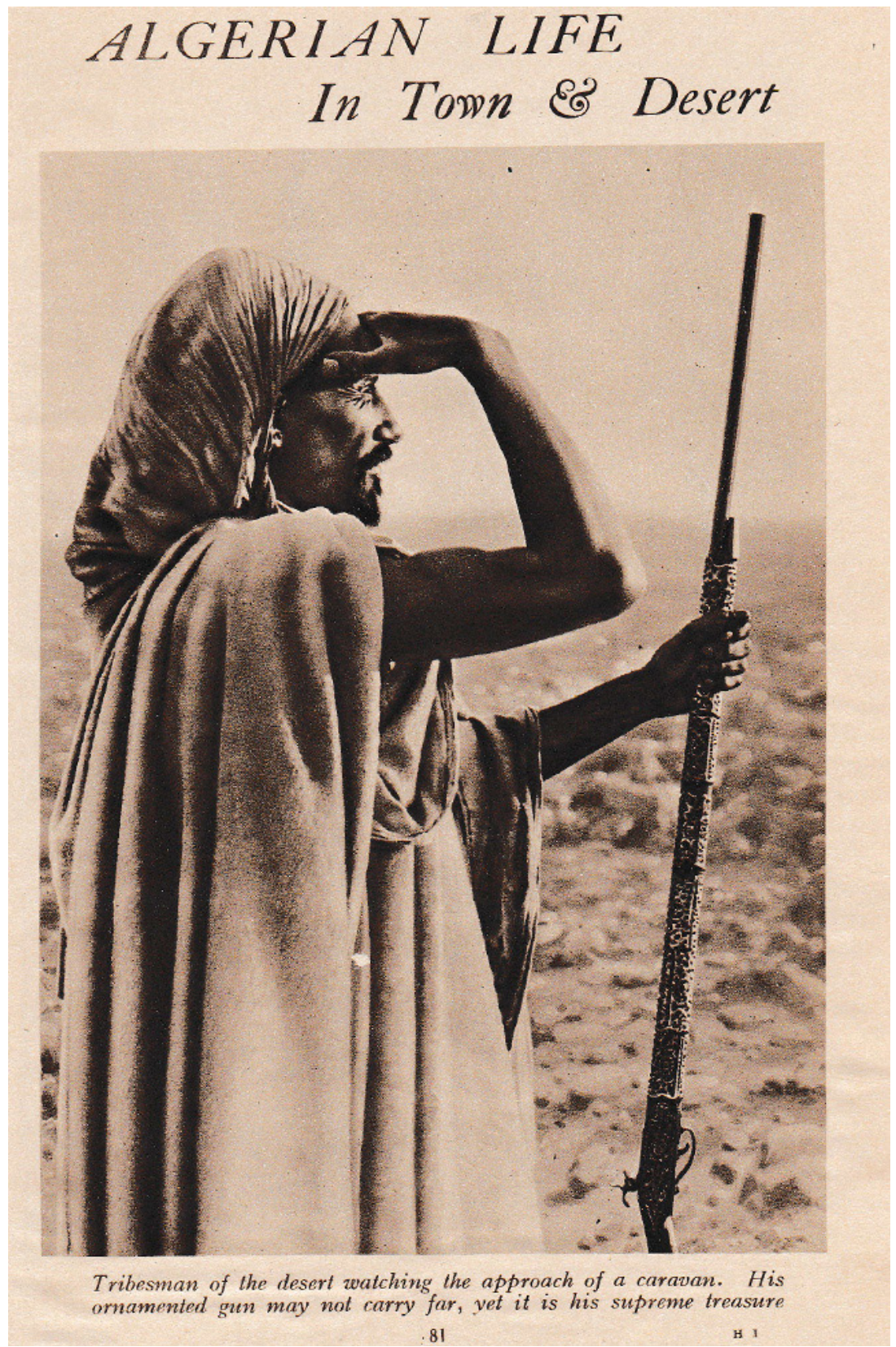




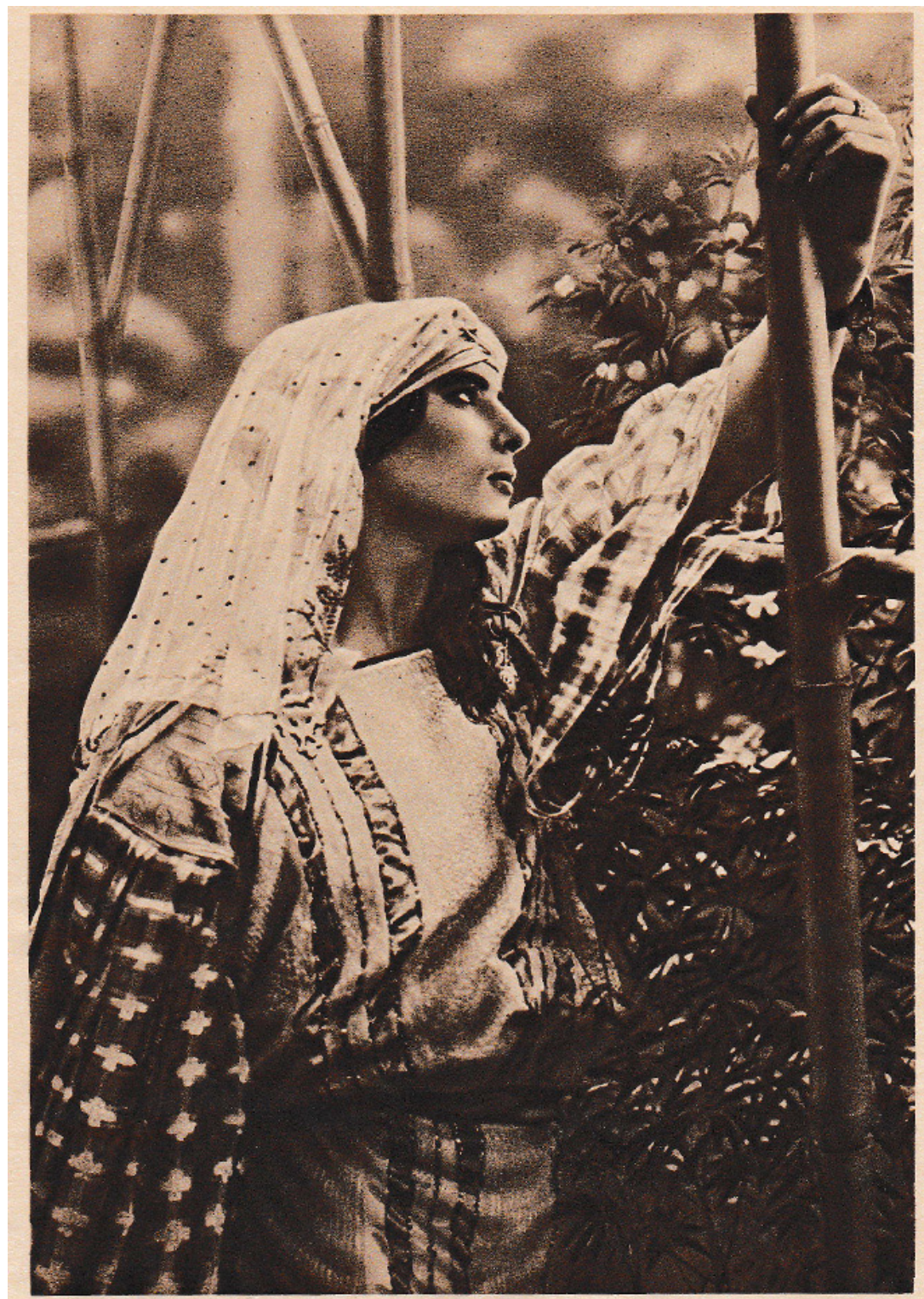

The Arab beauties of the old ruling class in Algiers are seldom seen unveiled, except by their husbands, parents, and the women of the harem 


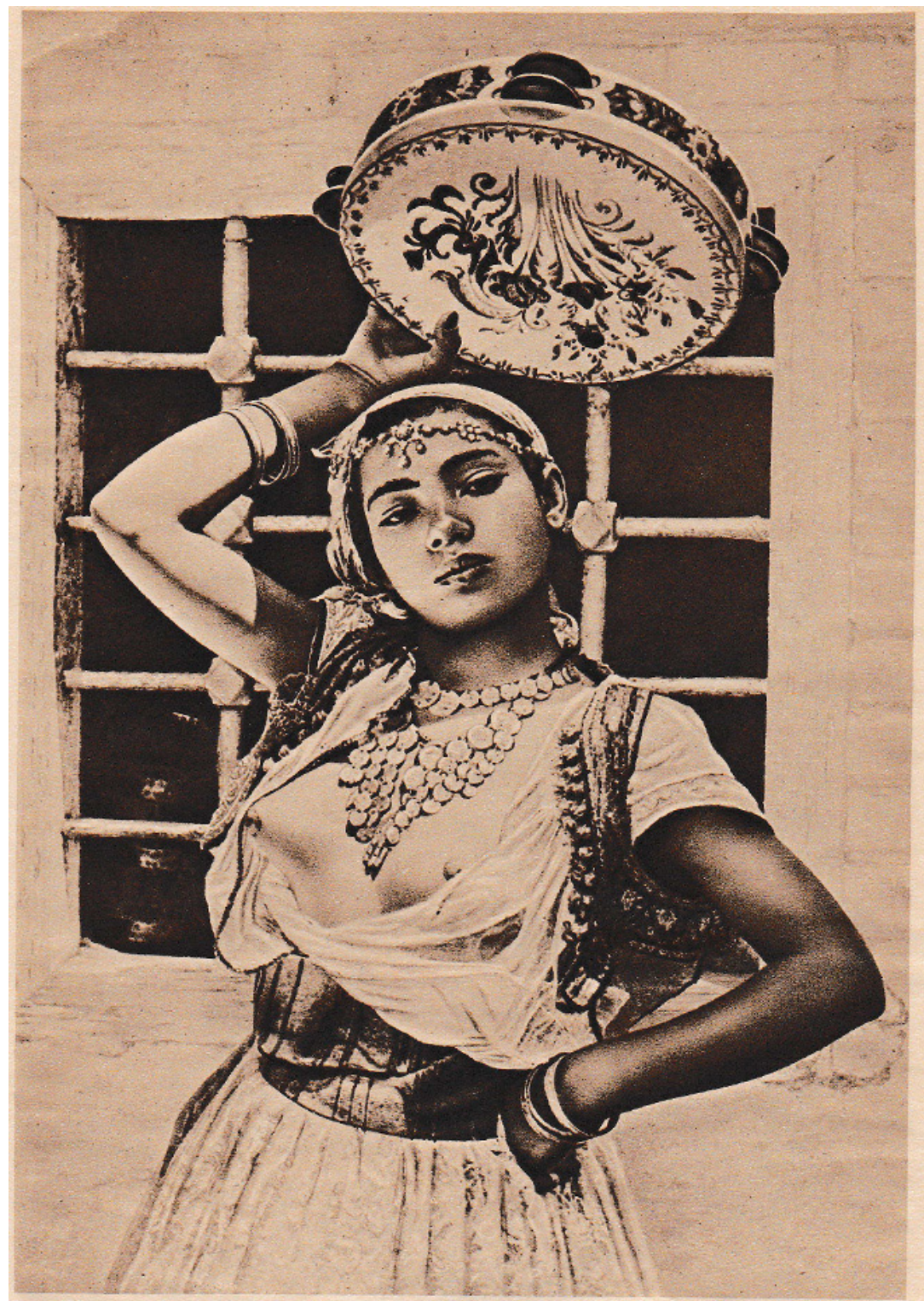

Her tambourine serves as collecting-box, as well as accompaniment to her dancing, in the Biskra cabaret, where she is the star attraction Photo, Crété 


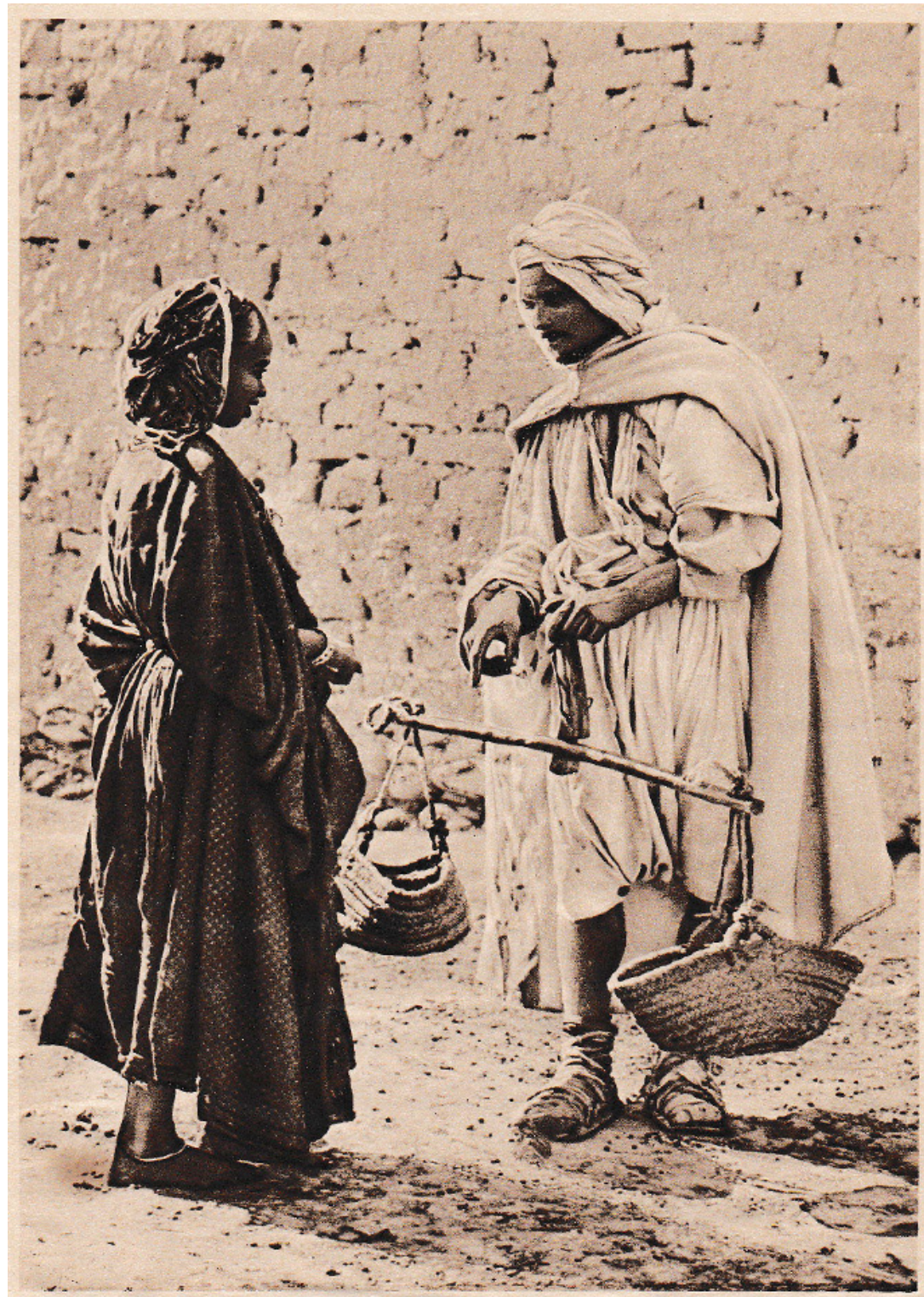

An Arab costermonger, looking as romantic as a robber sheikh, weighs out vegetables to a negress. His scales allow manipulation! 


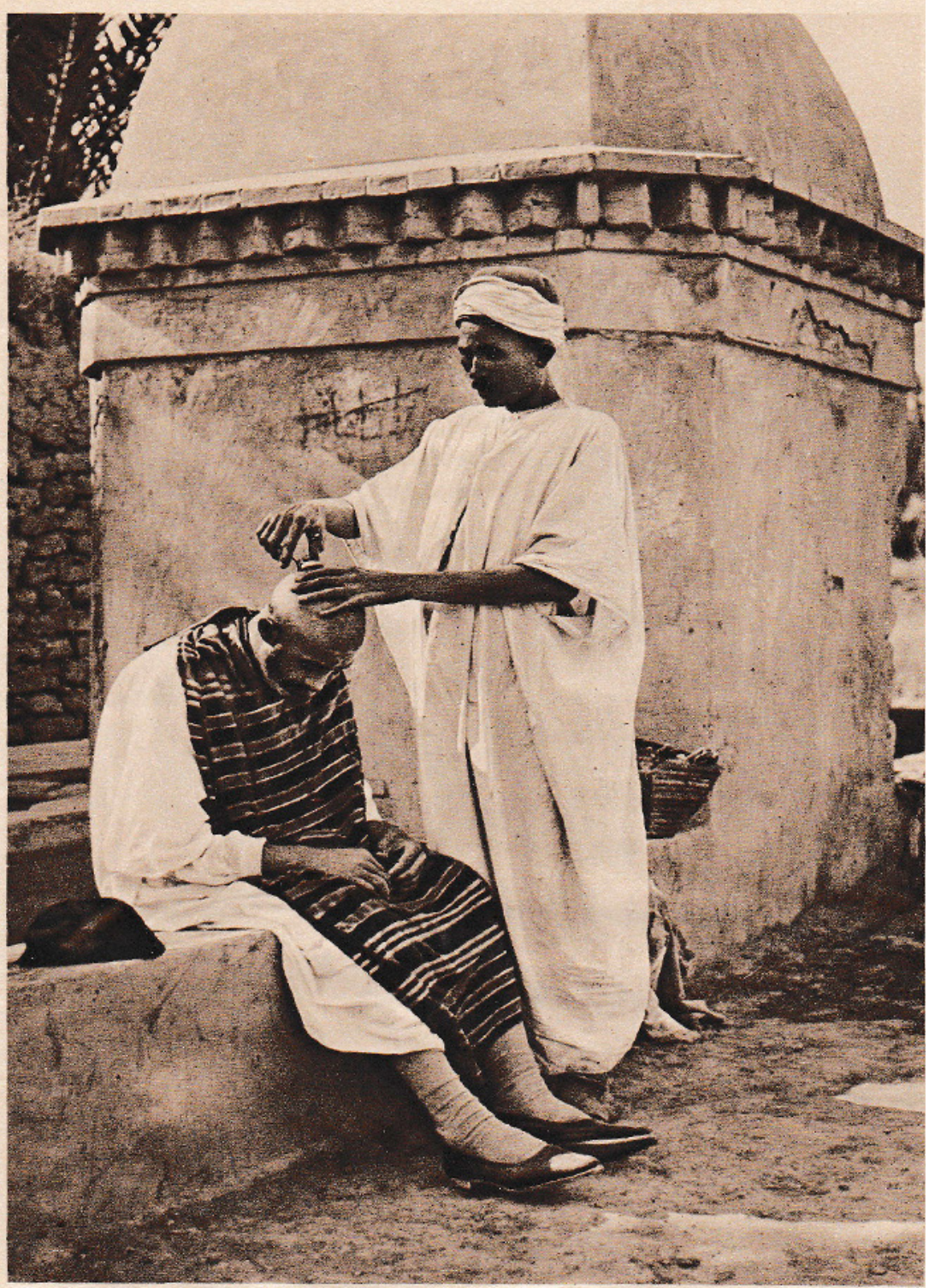

This is the public way Saharan barbers shave a customer's head. Usually one tuft is left by which angels can haul him into Paradise Photo, Donald McLeish 


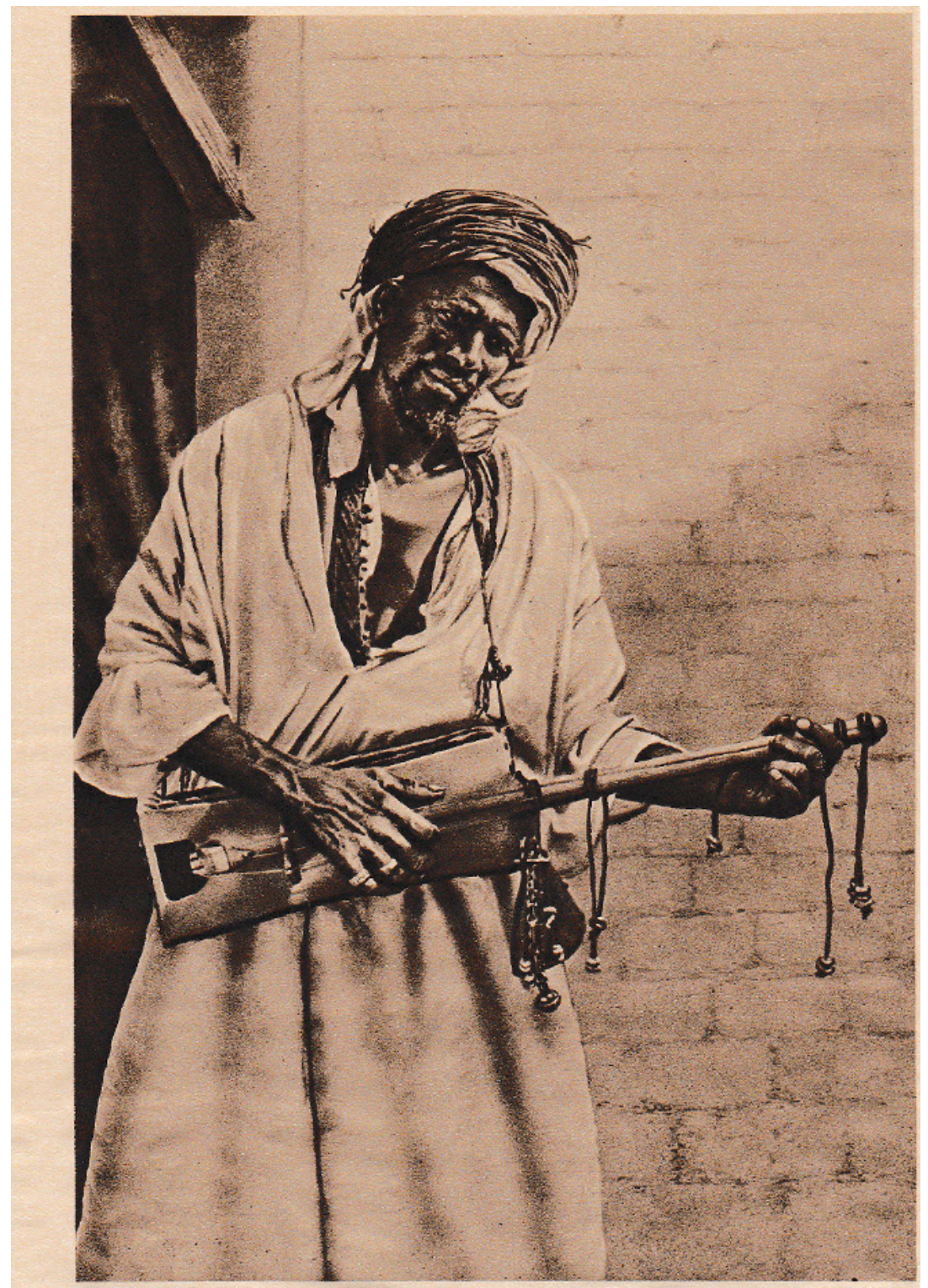

Negro minstrel of Algeria strumming monotonous airs on his quaint guitar, while his face is a study in the art of mendicant pathos Photo, Crété 


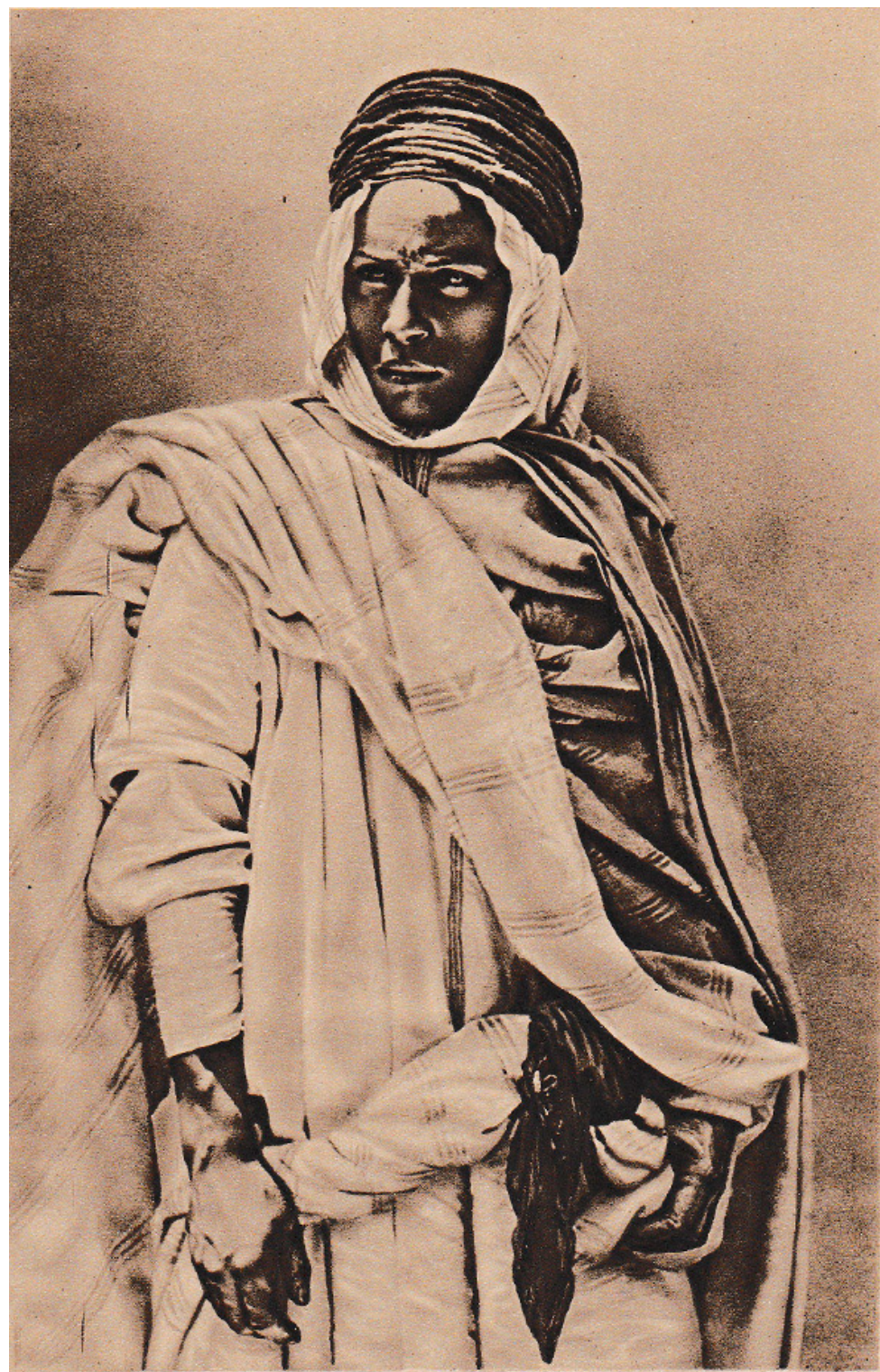

Berber mulatto of Northern Sahara. Since his tribe aided France against the white Berbers the mulatto has been pampered and proud Photo, Crété 


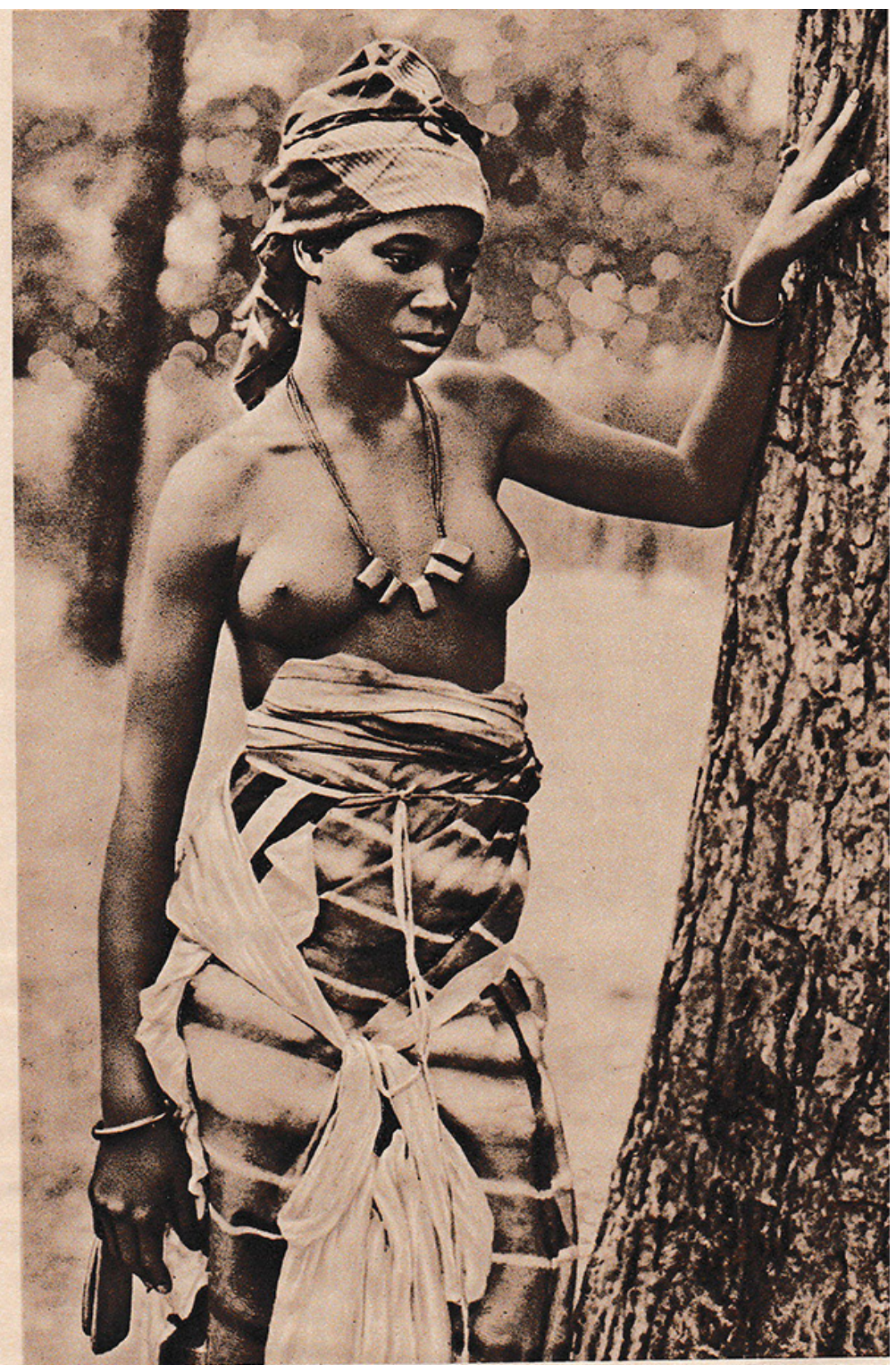

A young negress who cares little for modern conventions of dress in Algiers. Amulets on her bosom are meant to protect her charms Photo, Crété 


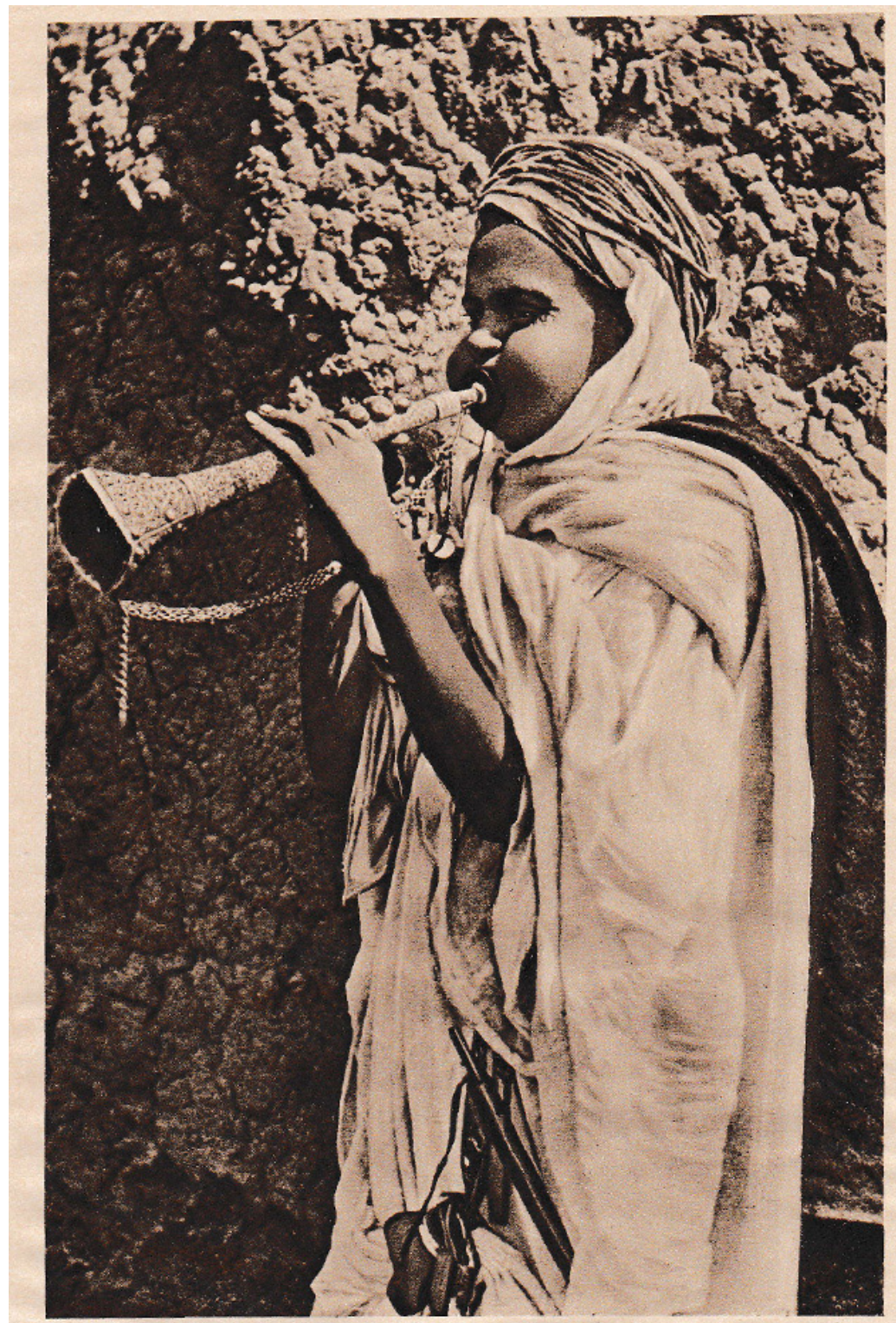

Fortissimo! The Saharan negro's zest for noise rather than music: even a delicate reed instrument he blowes like a trombone Photo, Crété 


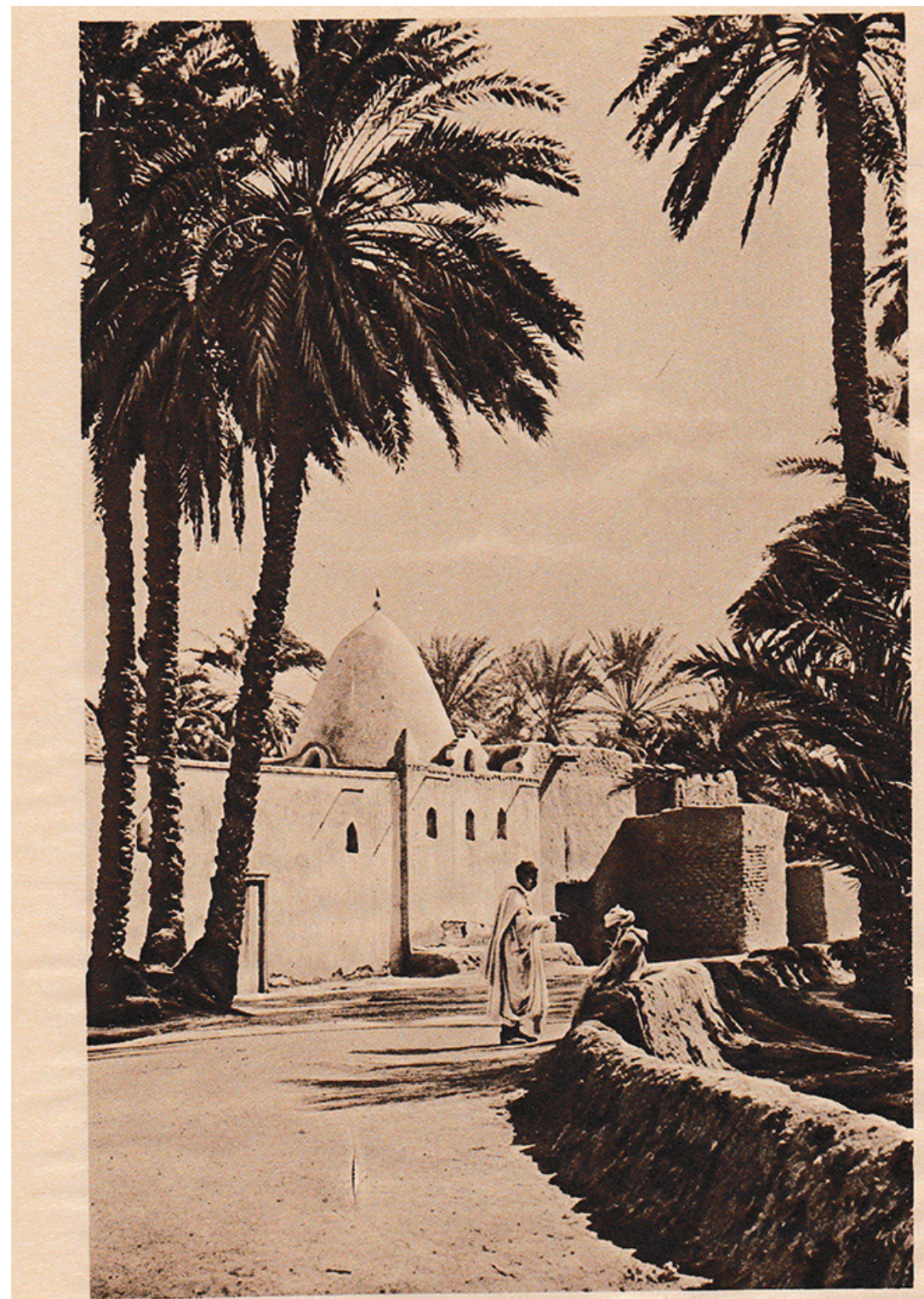

Old village mosque, standing amid myriads of feathery date palms, in the lovely oasis of Biskra, now famous as the "Garden of Allah" Photo, Donald McLeish 


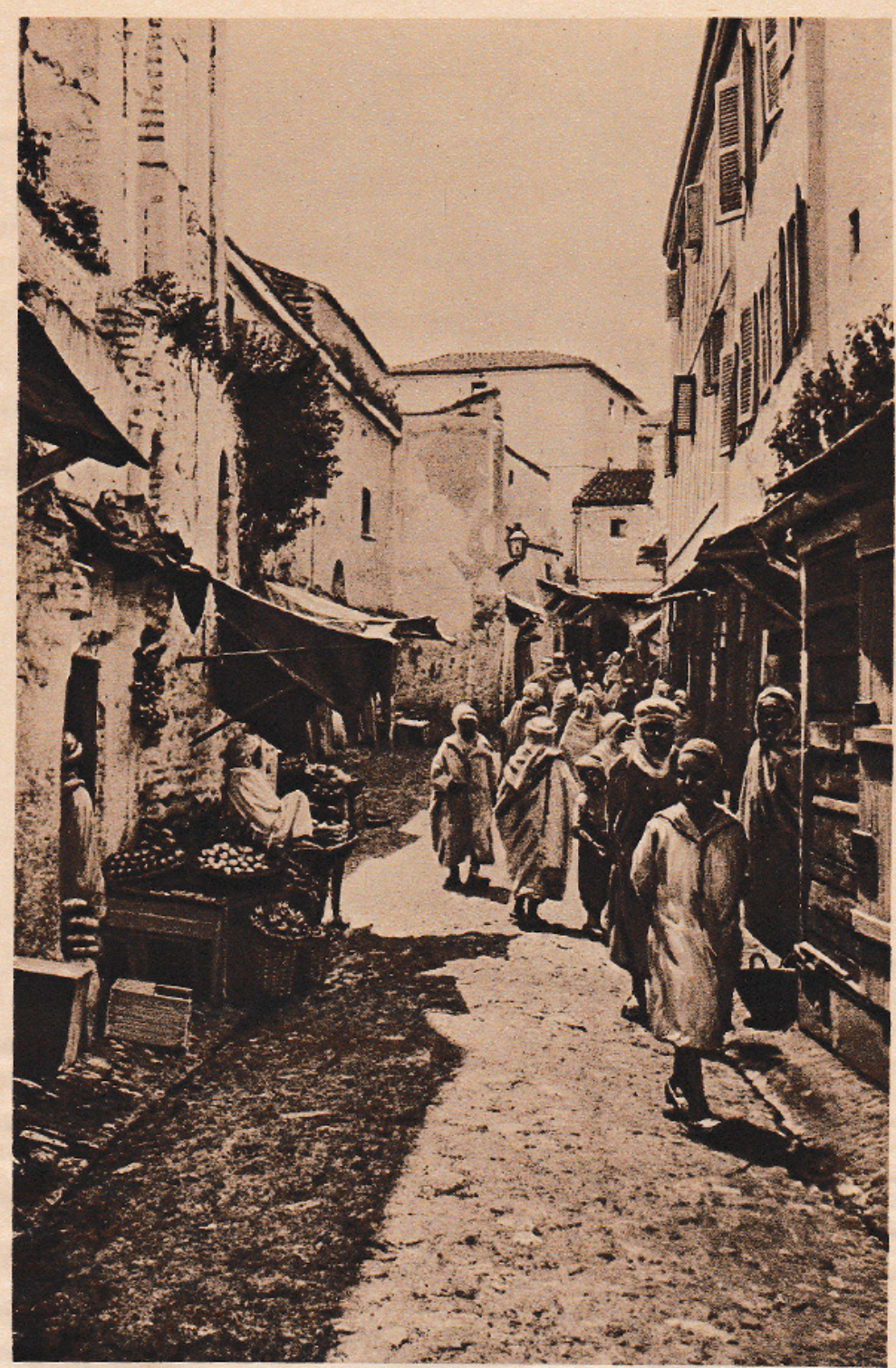

Quaint old Sidi Okba street in Algiers, with its stream of dark faces and white burnouses, retains the exotic wild charm of bygone days Photo, Henry Perrin 


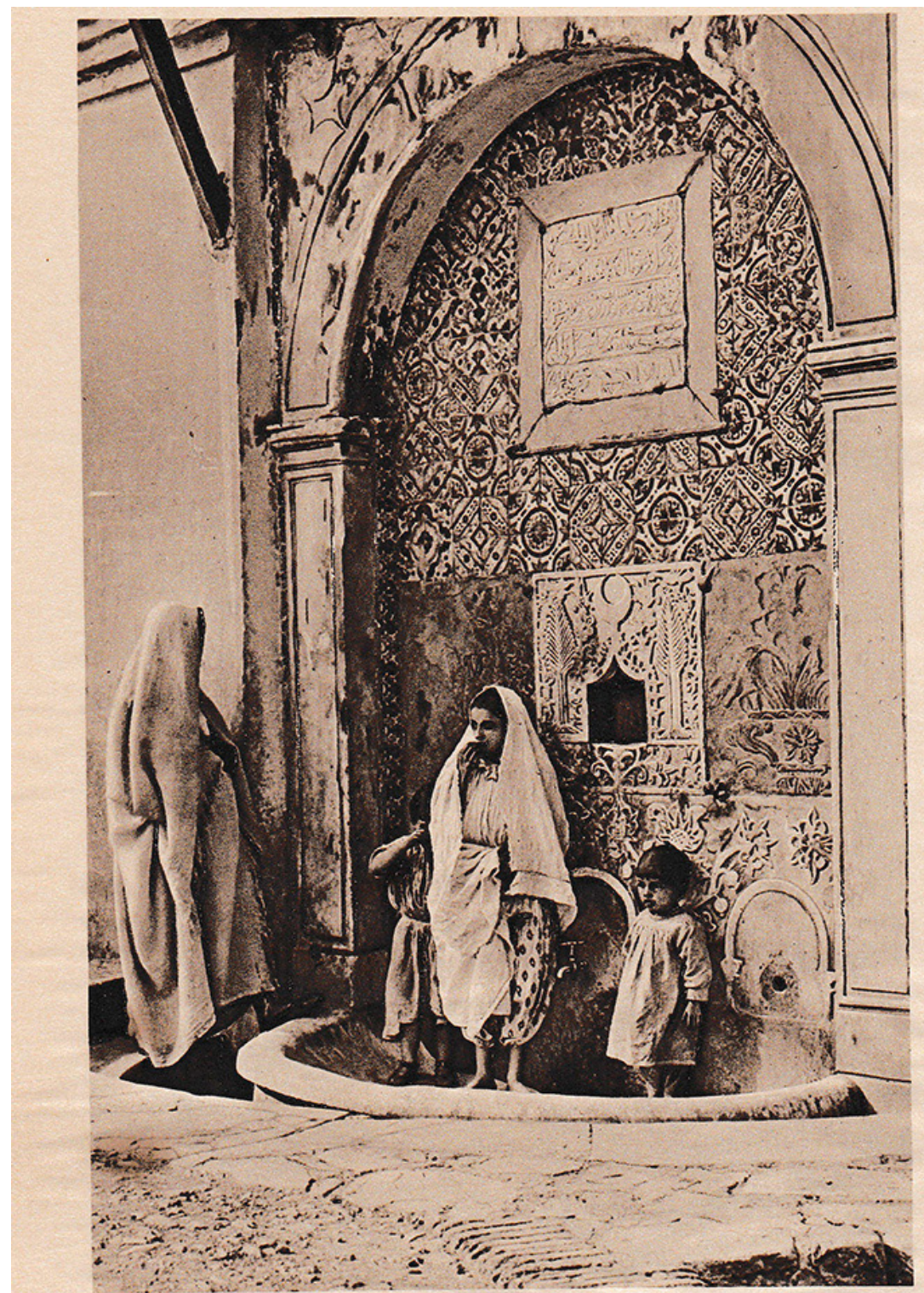

Graceful group of natives by a fine, ancient fountain in Algiers. The barefooted girl, with baggy trousers, is a pretty town type Photo, Donald McLeish 


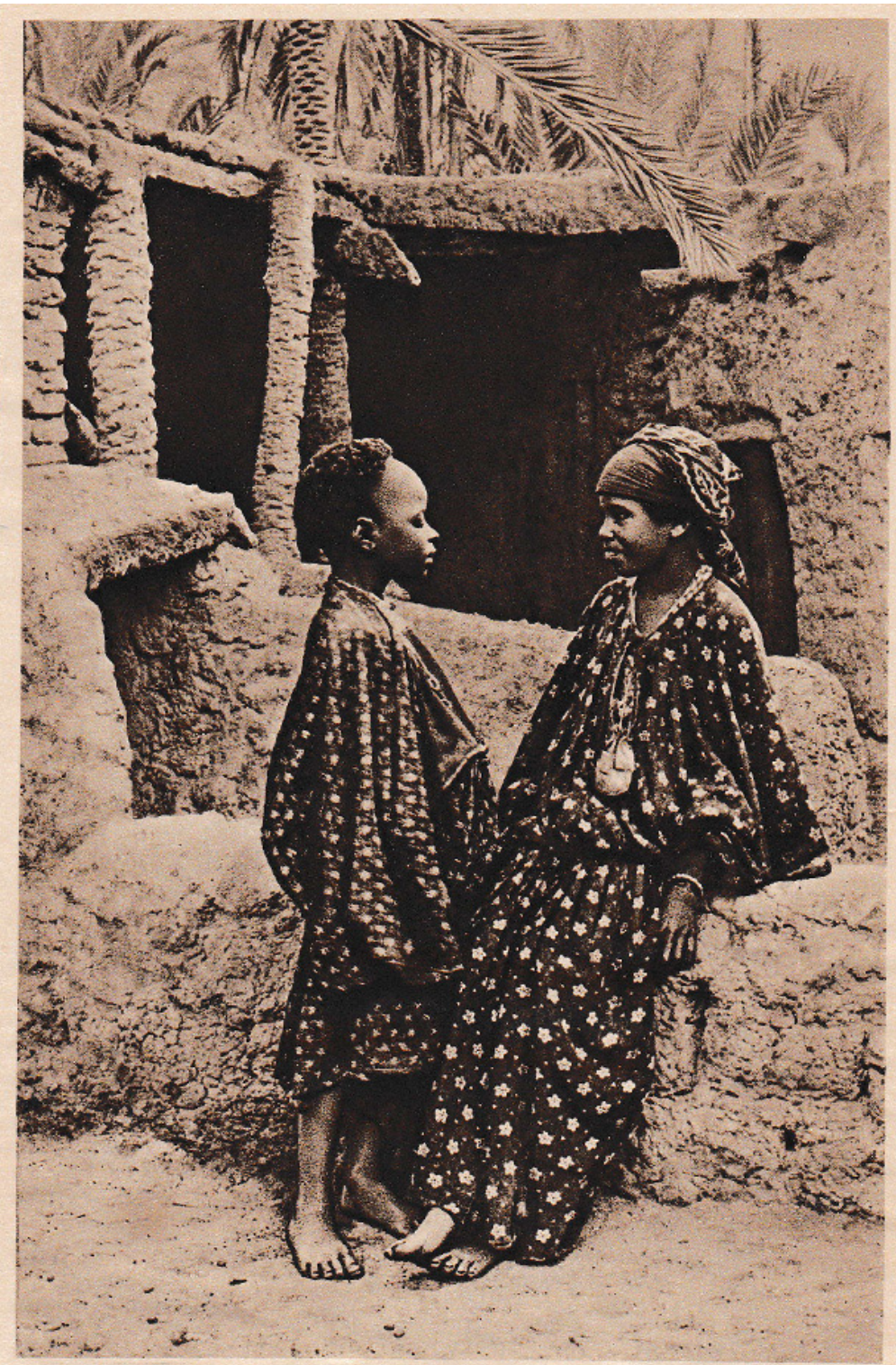

Girls of a northern oasis, showing the effect of seventy years' French culture; and, in the taller, the lingering faith in fetish charm bags 


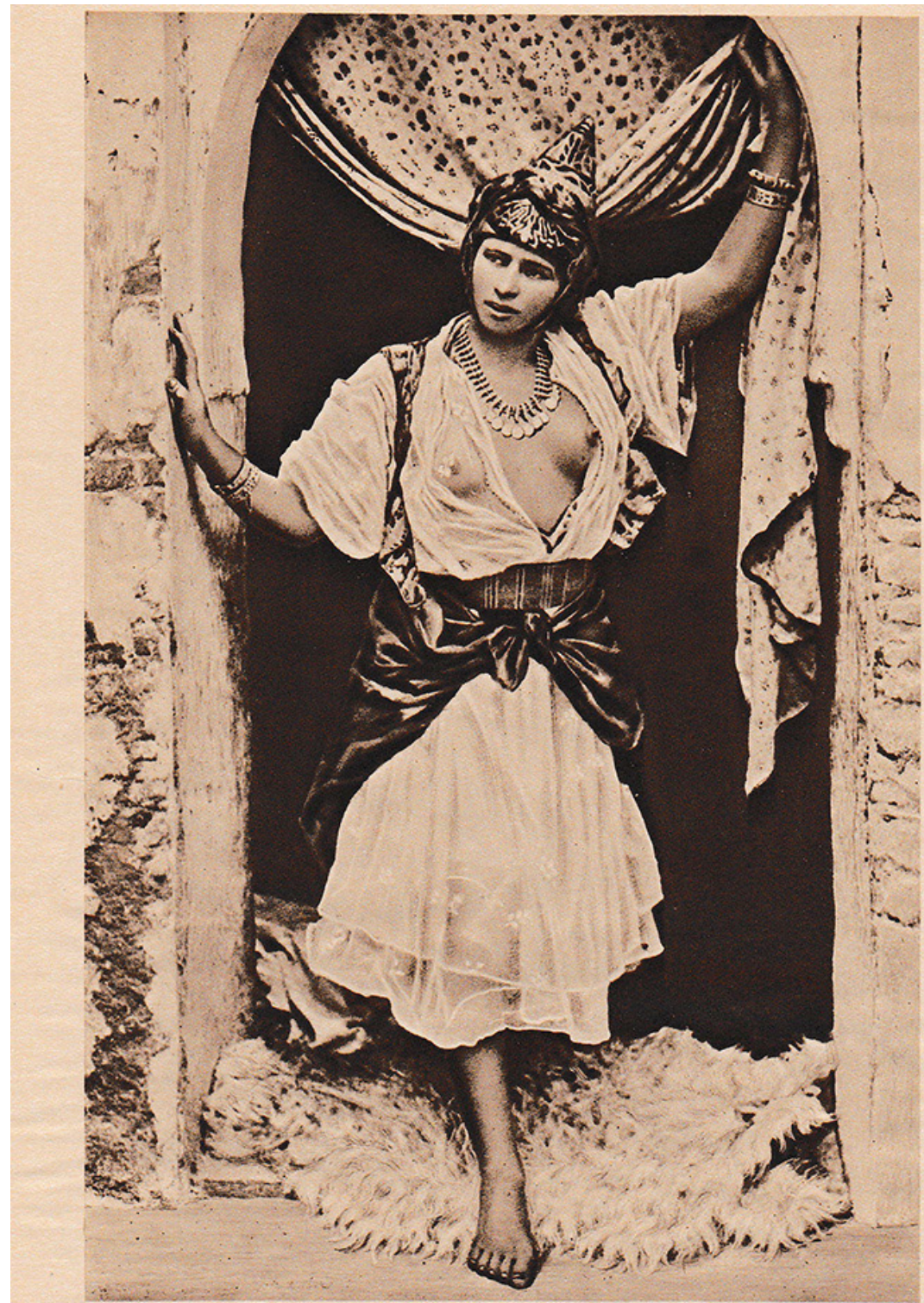

One of the Mauresque dancing women in whose veins runs the blood of European women captured by Algerians in the old piratic days Photo, Crété 


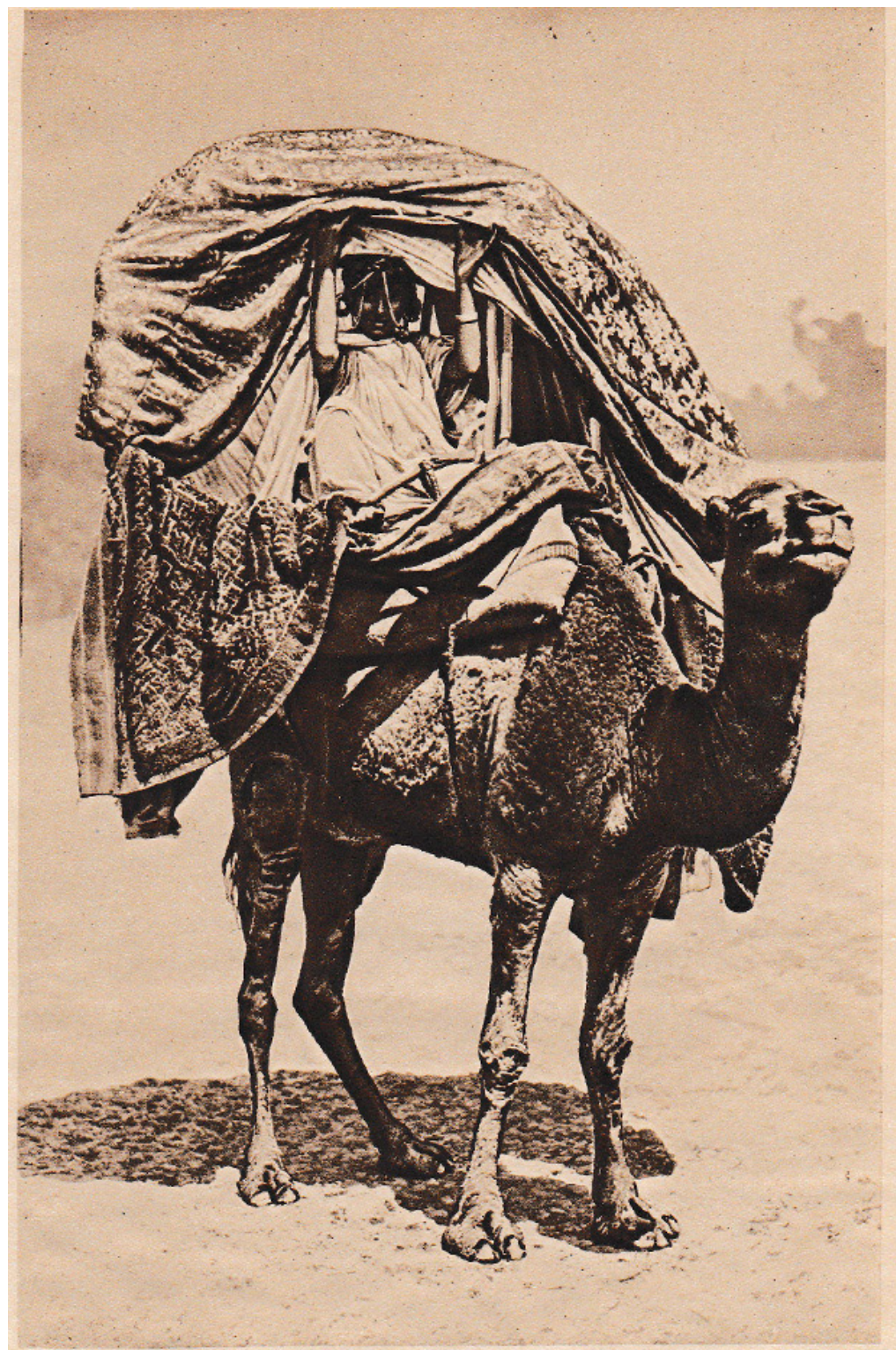

In her swaying camel litter, a desert beauty with barbaric ornaments keeps to the custom of the veil by carpet hangings easily lifted? Photo, Crété 


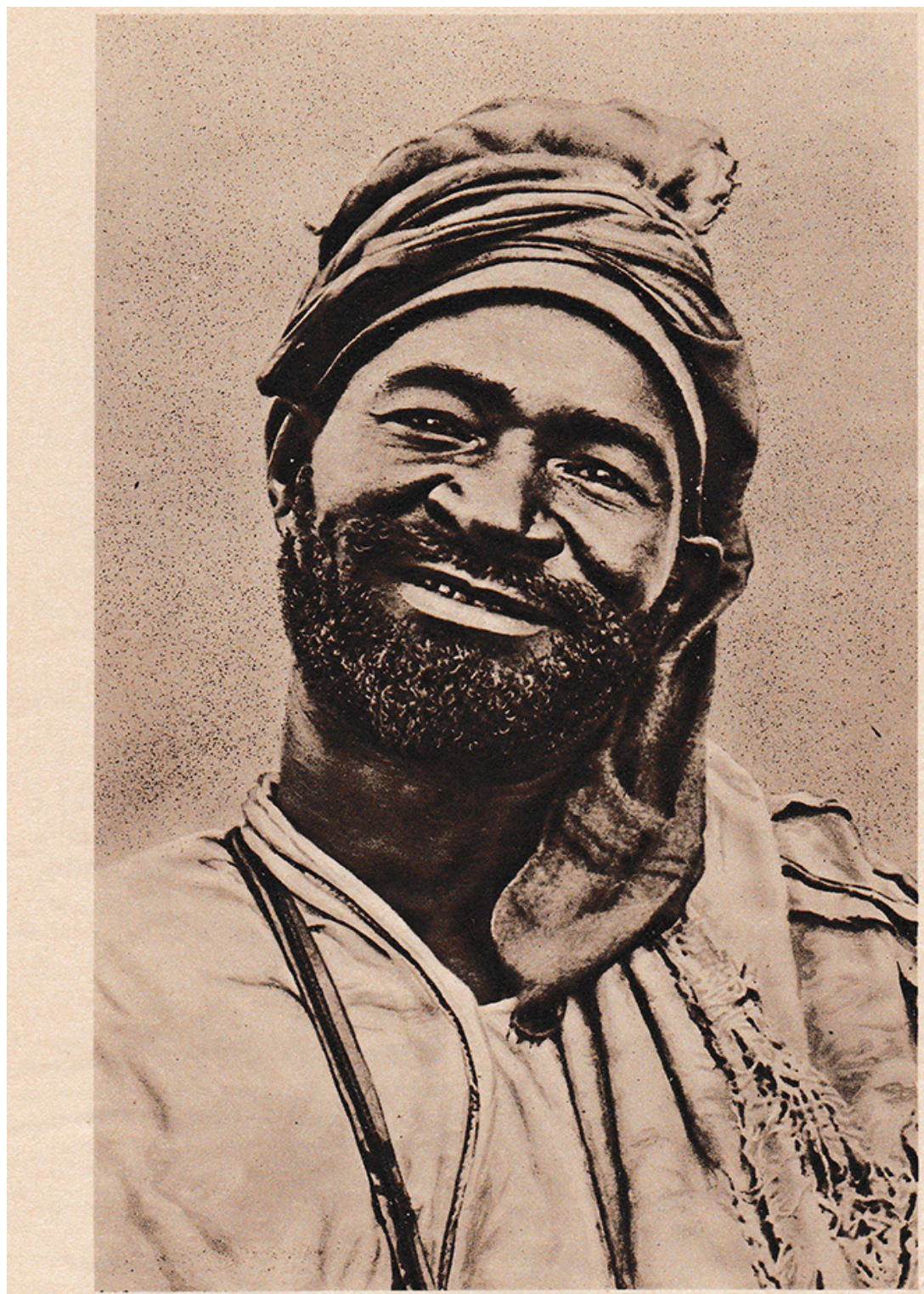

Like this jolly, swaggering negro, many of the blacks of Algeria are happy, self-satisfied fellows. There is no colour-line in Islam Photo, Crété 


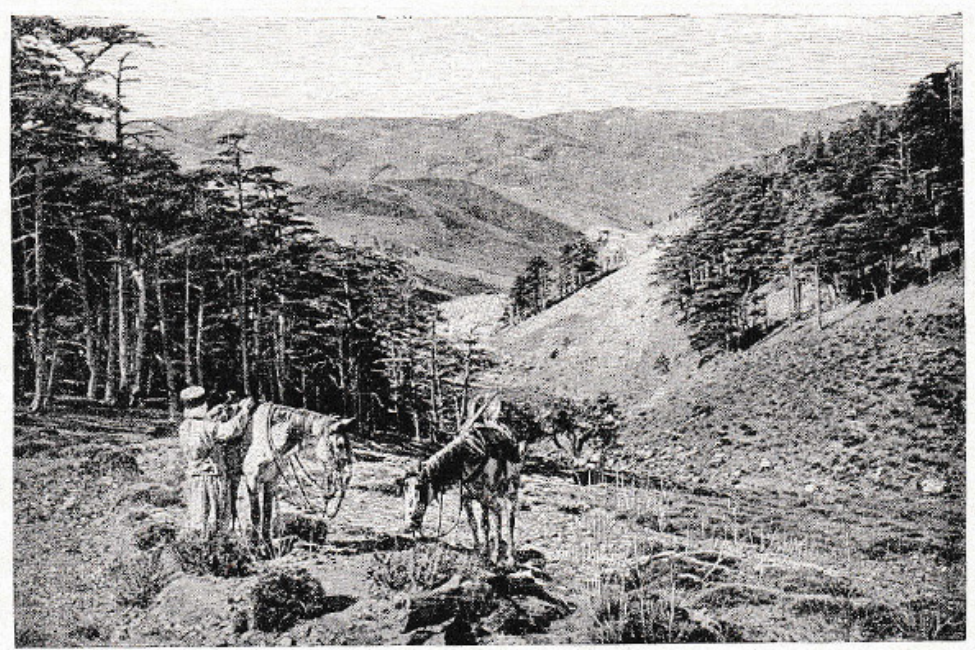

MOUNTAIN RAMPARTS BETWEEN CIVILIZATION AND SAVAGERY

From its cedar-dappled flanks the huge, broad masses of the Aurès can be seen rising some 7,650 teet to the crest of the Chelia. On the near side it stands above lakes and tilled fields to which raiders cannot penetrate. On the farther side it pours its streams into the Touggourt wastes

The space between the Great and Little Atlas is occupied by a tableland some 2,000 or 3,000 feet high.

The higher peaks of the Great Atlas are within the region of perpetual snow, and the drainage from them feeds many rivers, some of which are lost in the Desert sands to the south, and others cut their way north through numerous gorges and valleys to the Mediterranean. The high platean is swept by snowstorms in winter, and in summer bears large crops of alfa or esparto grass.

Besides Algiers there are a number of ports along the coast from which an extensive trade is done in the fruits of the Tell and the esparto grass from the high plateau. Oran, in the west, has a large Spanish element in the population. Bougie, Philippeville, and Bona are east of Algiers, on harbours which the Phœenicians first exploited.

Of all the inland towns the most remarkable is Constantine, which, under the name of Cirta, was the native capital of Numidia before the Romans came. It had its origin in a prehistoric rock fortress, and for moat it has the wild and romantic gorges, nearly $\mathrm{I}, 000$ feet deep, of the River Rummel, which circles round it. No city in the world has a more picturesque and remarkable situation.

The southern territories of Algeria, which are under a separate administration, stretch far into the burning sands of the Sahara, and the railway has now been pushed beyond Biskra to the distant oasis of Touggourt. Contrary to expectation, the Desert sustains a considerable population. It is interspersed with oases, many of which contain great forests of date palms.

The chain of oases in the Oued Rirh, on the way to Touggourt, contains 600,000 date palms, and supports a population of $\mathrm{r}, 7 \mathrm{OO}$. The wild Tuaregs have been tamed, and now bave a greater interest in the date harvest than in plunder. The oases are occupied by numerous tribes of Berber, Arab, Jewish, and Negro origin, some of whom, like the Mozabites, are famed as traders all over the country.

The French people, as a race, have a marvellous capacity for the logical development of an idea, and nowhere 


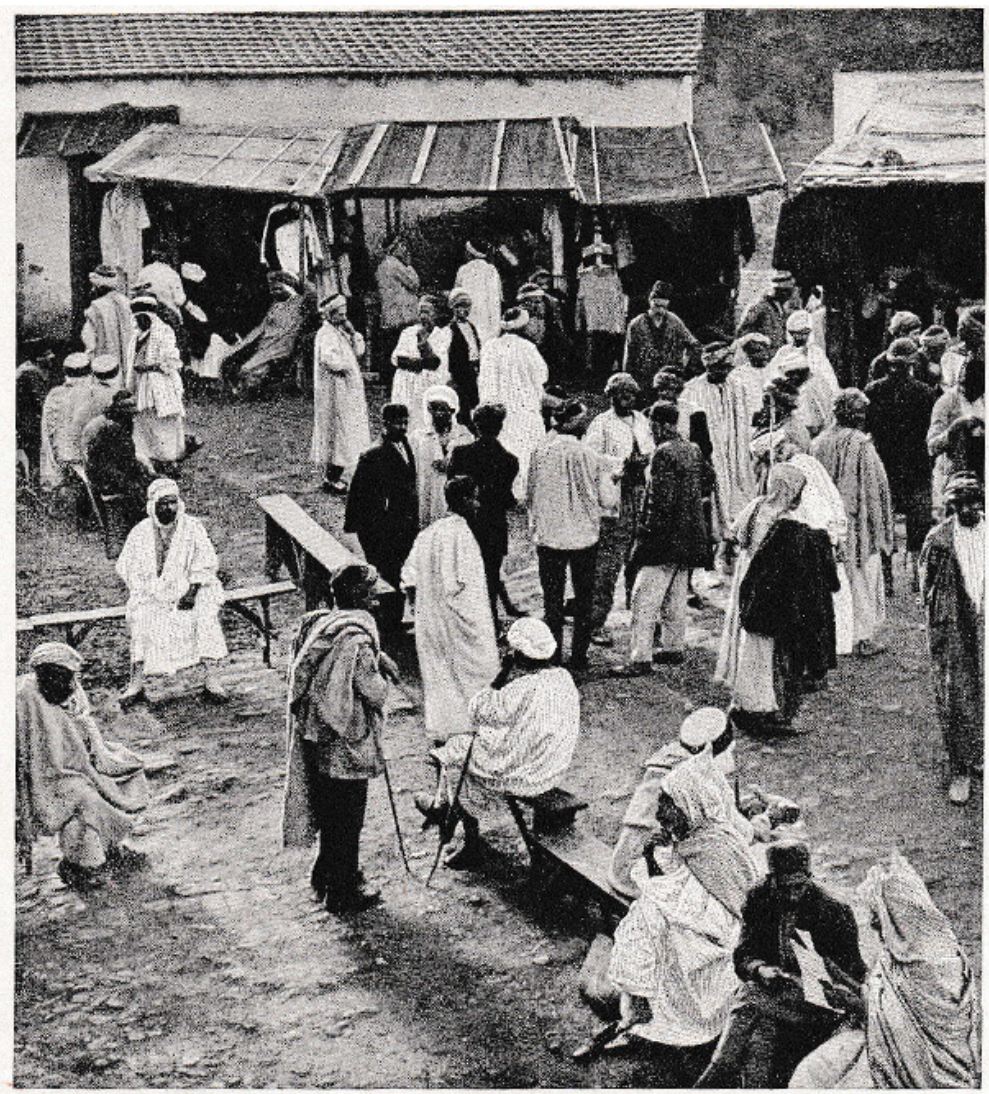

WHERE THE ALGERIAN MOOR IS BEST SUITED

In the clothiers' market in Algiers no man tries on a new garment in a shop. He walks out into the crowded centre of the market-place, and, after being fitted, takes the admiration and criticism of the public. Then follows a long dispute over the price, with the crowd as clamant chorus

Photo, Donald MoLeisth

is this trait more evident than in the manner in which they have dealt with Algeria. With conscious purpose they have set before themselves the Roman model. Their great military roads and railways which have opened up the country, their extensive irrigation works, their municupal development, their encouragement of agriculture by European colonisation their great permanent military camps, their dealings with the native population, and their lavish extension of the rights of French citizenship, are Roman in intention. The modern Frenchman finds Paris in Algiers, just as the Roman found the Forum, the Market Place, the Theatre, the Temples, the Baths of Rome at Timgad on the slope of the Aurès Mountains.

Many races have mingled their blood in North Africa since the days of the Romans, but the indigenous native stock remains in essential respects the same. The Berbers speak the same language to-day as they spoke in the 


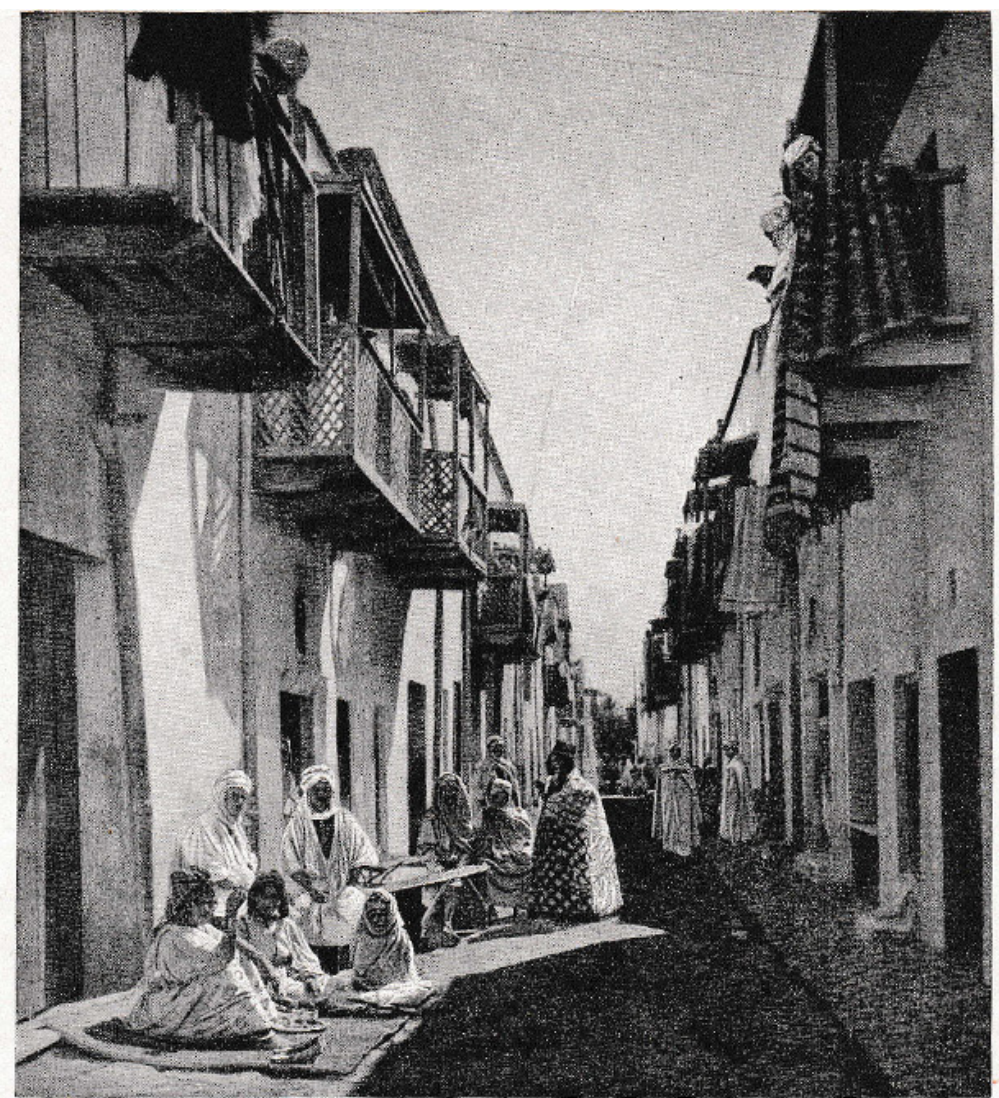

SIRENS OF THE SANDS IN BISKRA'S HOLY STREET

When thetr training is finished, the girls of the Ouled Nail often make their first appearance in a Biskra alley, oddly named "Holy Street." Squatting on their dancing-carpets in the open air, or lcaning from their balconies, they gaily await admirers of their arts and charms

Photo, A. Bosparth

days of the Phøenicians and the Romans. The chief branches of this widespread race are the Kabyles and the Shawias, the highland tribes of the two great mountain ranges of Djurdjura and Aurès respectively.

In the gorges and valleys of these mountains they have preserved the purity of theit race and language in a remarkable degree. Many of ie Desert tribes are of Berber ongin. As a race they have many European characteristics, and they are supposed to be a branch of that Iberian stock which once populated the northern shores of the Mediterranean, and even reached as far north as Britain. With the exception of those who have acquired the nomad habit from the Desert, they are an industrious agricultural and pastoral people.

The Phonicians, the Romans, the Vandals came and passed, leaving hardly a racial trace. There were great numbers of them, but they were absorbed. The Asiatic races, the Arabs, and the Jews have preserved their 


\section{ALGERIA \& THE ALGERIANS}

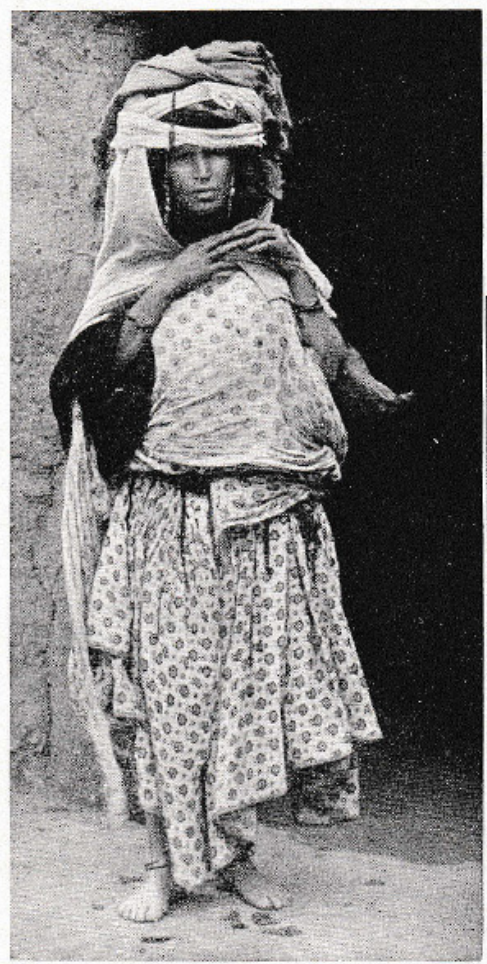

NEW CLOTHES, OLD FASHIONS

This Biskra woman thinks that dress is civilization, but she wears the old grease, wool, and hair frame for her saffron-dyed face

$$
\text { Photo, Donald MeLeish }
$$

type more persistently, but even the Arabs show signs of becoming merged in the indigenous stock. The so-called Moors, who inhabit the towns and the coast villages, and who carry on the trade and crafts of the country, are really a mixed race, showing the Arabs in process of absorption.

Religion has kept the Jews a separate and exclusive community, as it has done throughout Europe. A relic of slavery is the noticeable infusion of negro blood.

France has laboured to promote European colonisation by generous grants of land, and by scientific irrigation, railway development, and education. The soil is rich, the climate is sub-tropical. The elevation of the tableland gives it a European character, and in the Tell, the broad belt where the tableland breaks down to the coast, intersected by fertile valleys and plains, moisture is abundant, and vegetation luxuriant. Here

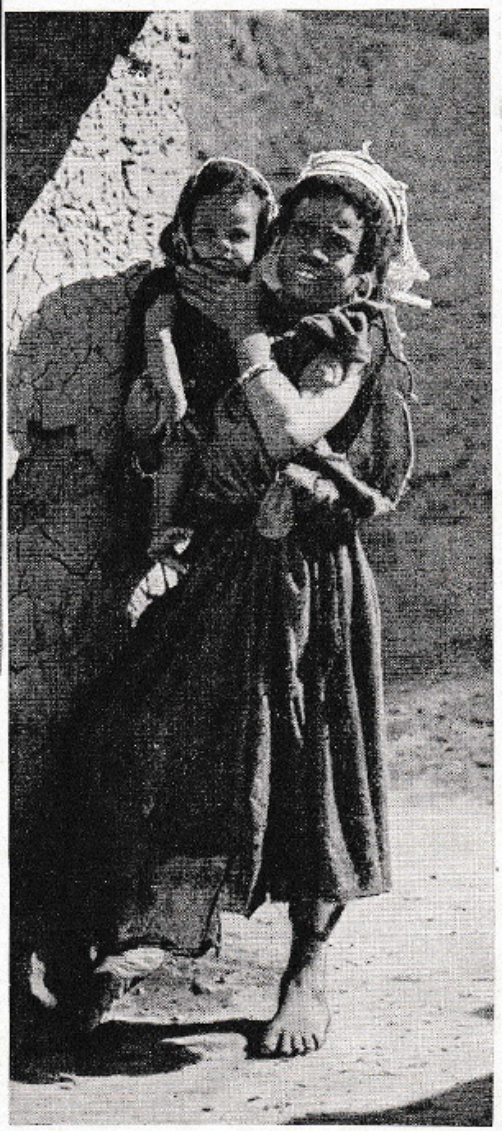

BABIES THEY LEAVE BEHIND THEM Biskra's wealth of mulattoes is largely due to the Senegalese negroes of the garrison of the oasis town, whose temporary alliances completed the work of the old slave-hunters

Photo, Donald acterish 


\section{Biblioteca}

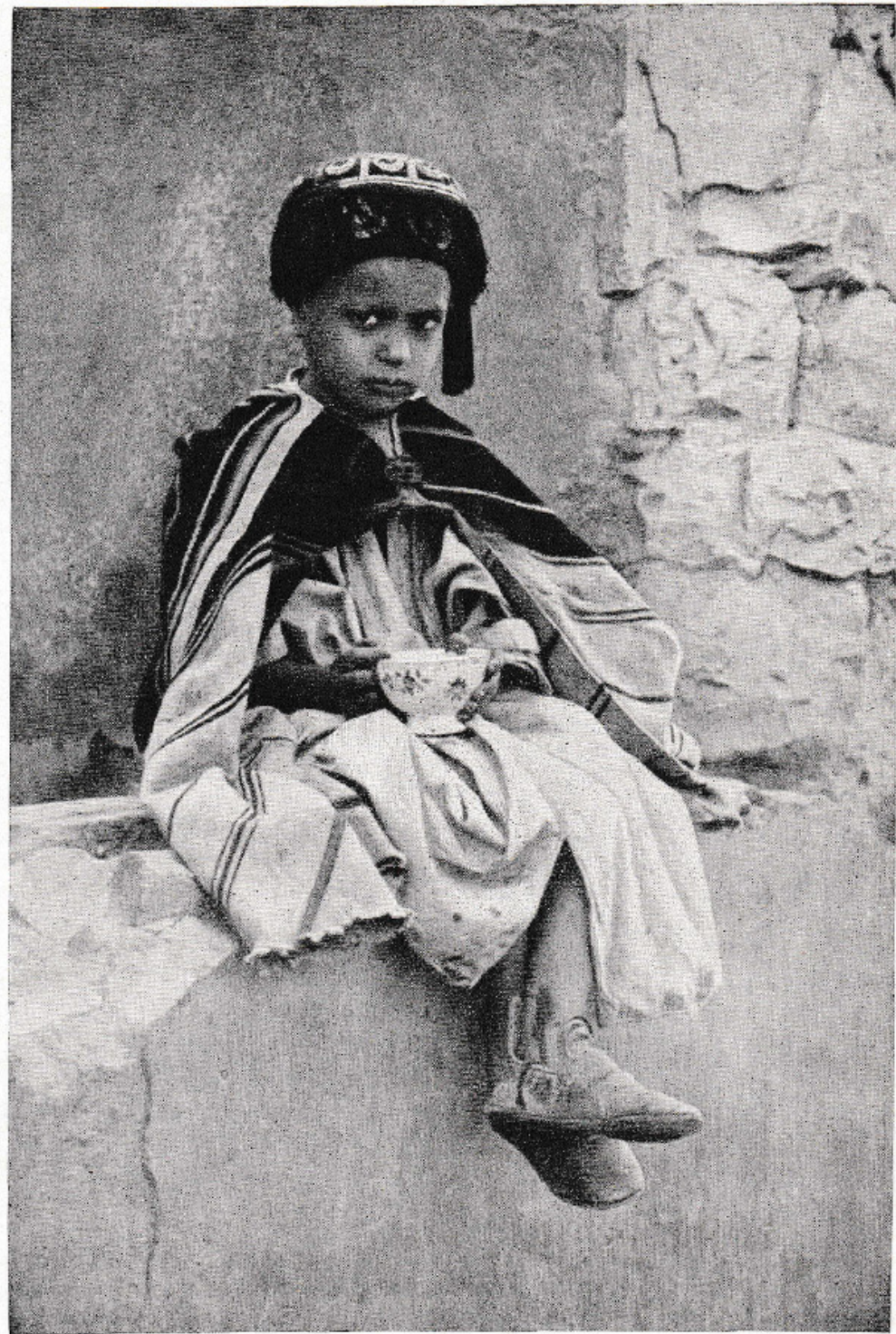

THE CHILD WHO IS FATHER TO A NATION IN THE MAKING

In the expanding oases-land south of Algeria this improving type of the young half-breed is being gently crammed with modern knowledge by French schoolmasters, while the fanatic marabouts try to keep him in Islam with Koran lore. He is the new mulatto; as he shapes so will a nation Photo, Donald McLoish 


\section{ALGERIA \& THE ALGERIANS}

flourish the vine, the olive, the fig. the orange, the lemon, the almond and the tobacco plant. Vineyards and groves extend on every side. On the wide alluvial plains of the Mitidja and the Chelif large crops of wheat, barley, and oats are raised.

Up on the tableland the soil lacks sufficient natural moisture, but responds readily to Irrigation by artesian wells. The nomad dwellers on these high plains pasture great herds of cattle, sheep, horses, mules, and goats. Enormous quantities of esparto grass (alfalfa) are collected and exported for paper making.
The date palm grows luxuriantly all over the country, but its fruit ripens only in the Desert; not north of the thirty-third parallel of latitude. It stands, as the Arab proverb says, "with its feet in the water and its head in the fires of heaven." In the channels of the intermittent streams which flow down from the Atlas and lose themselves in the Desert, and in the oases which have been extended by irrigation, the palm spreads a perpetual canopy of grateful shade. Each tree produces from one to two hundred pounds of fruit in the season.

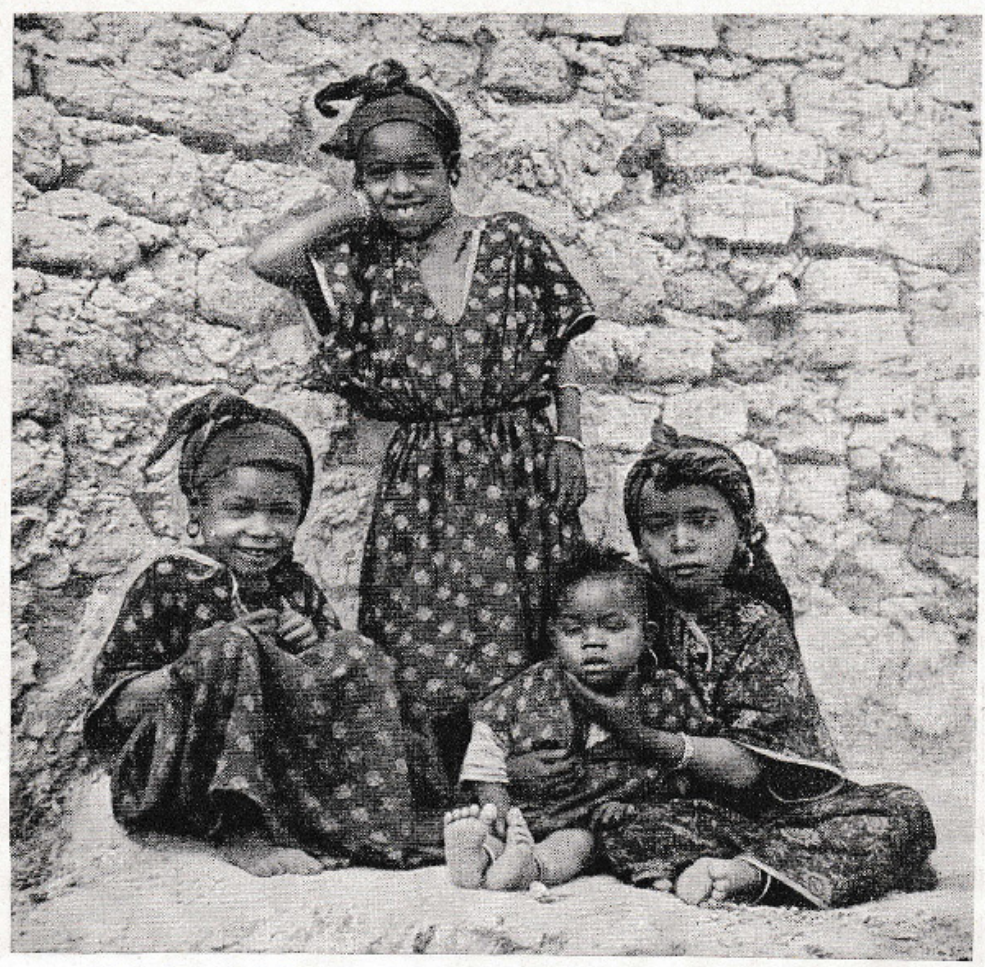

BITS OF LIVING JOY IN AN ARID WASTE OF DEAD SORROWS

These happy negro children of the oasis of Biskra are the best evidence of the humanising influence of France in Algeria. They are descendants of the miserable, diseased oasis slaves of the Tuareg tribesmen, who were marched like cattle from Timbuktu and then almost worked to death. The old place of doom is now gay with life in winter Photo, Donald McLeishi 


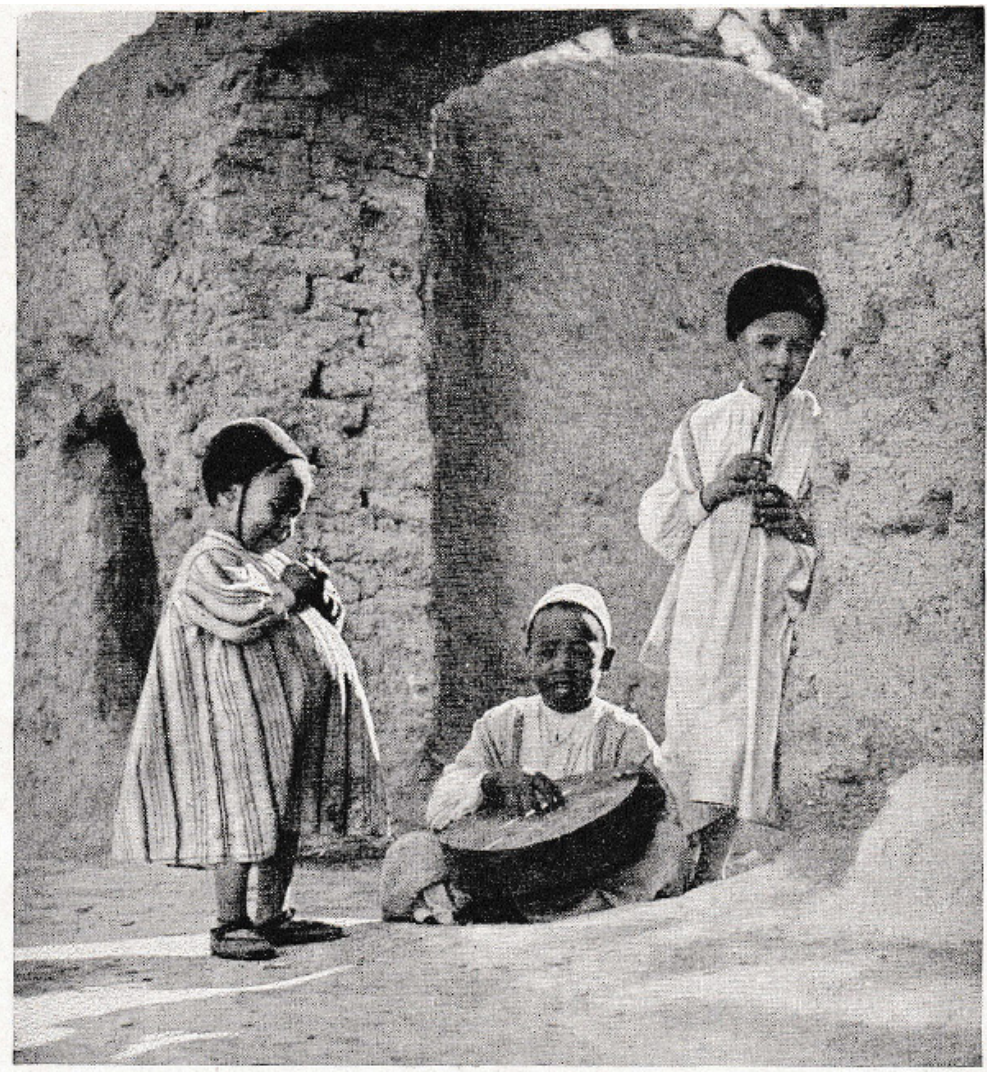

LITTLE MUSICIANS OF A GREAT OASIS

The fife of the Arab lad is made from a reed from an Atias svatercourse, and the tunc soc: wandering as it likes. The tambourine of the young negro is a sheepskin stretched over two wooden hoops; from it is beaten out a rhythm that doesn't agree with the fifing. The duet is symbotical of racial characteristics at Biskra

\section{Photo. Donald MALersh}

Without the palm, the Sahara would be uninhabitable. Its delicious, sweet, and nutritious fruit is a source of wealth to the Arabs, and the basis of a prosperous export trade.

In many respects this land is smlar to Palestine, the land flowing with milk and honey. It has the same climate, the same fertile belt along the coast, the same mountainous interior, and the same Desert beyond.

Such is the Promised Land which France has laboured for nigh on a century to Europeanise. Her success, in all material respects, has been great, surpassing even that of Rome in her first century. The Pax Gallica has been established. The rich lands which had relapsed into wilderness have been reclaimed. Colonists have been settled. The natives have been given the rights of French citizenship.

And yet, as Gaston Boissier confesses in his inspiring book on "Roman Africa," spiritually Algeria remains obstinately alien to Europe. The 


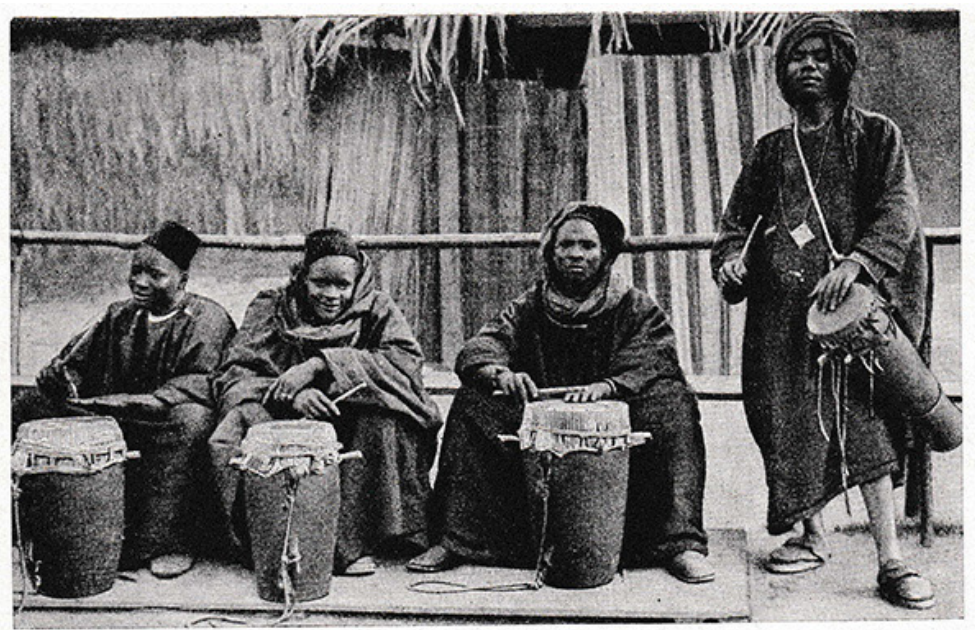

NEGRO MINSTRELSY IN ALL ITS PRIMITIVE CLEVERNESS

Out of the black heart of Africa comes the fierce element of strength in the weird music of old Barbary. With nothing but their four tom-toms, these negro drummers make a music of pure, pulsating rhythm charged with emotional effects that throb upon the nerves and sway the soul Photo. Crele

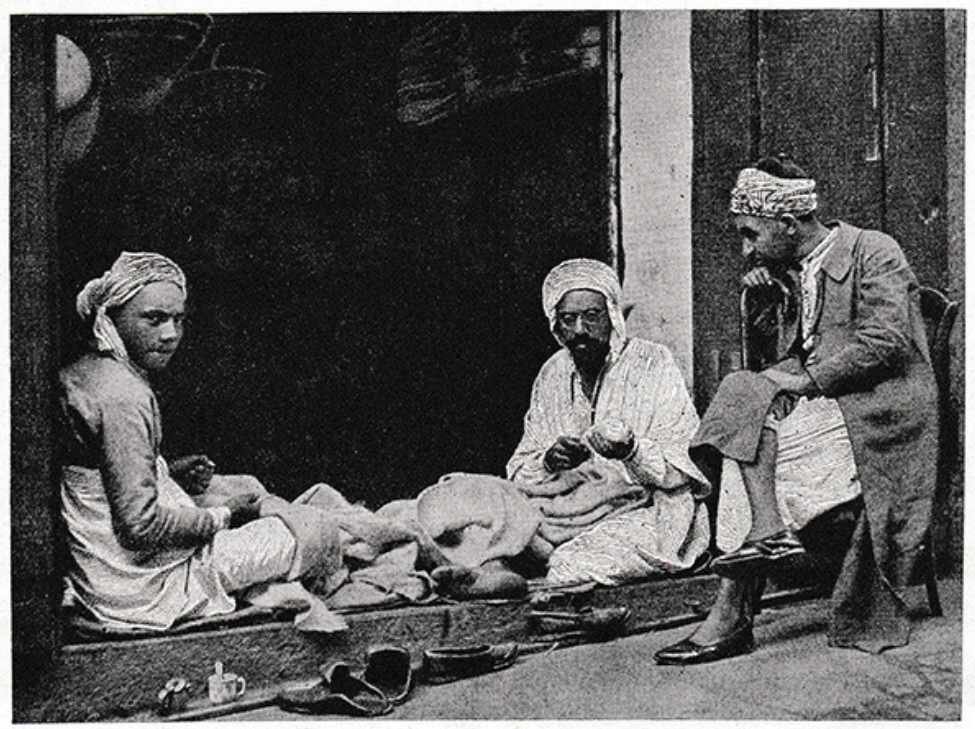

THE SHOP CAVE IN THE WALL AND ITS REASON

By the timiest of booths, these Algerian tailors are finishing a burnous, or long, white woonen cloak. Under the Turks, prosperity in shopkeepers was a crime; their descendants still squat at work by an open cave, however good their business, for this was the old way of avoiding confiscation Photo, Donald MeLeish 


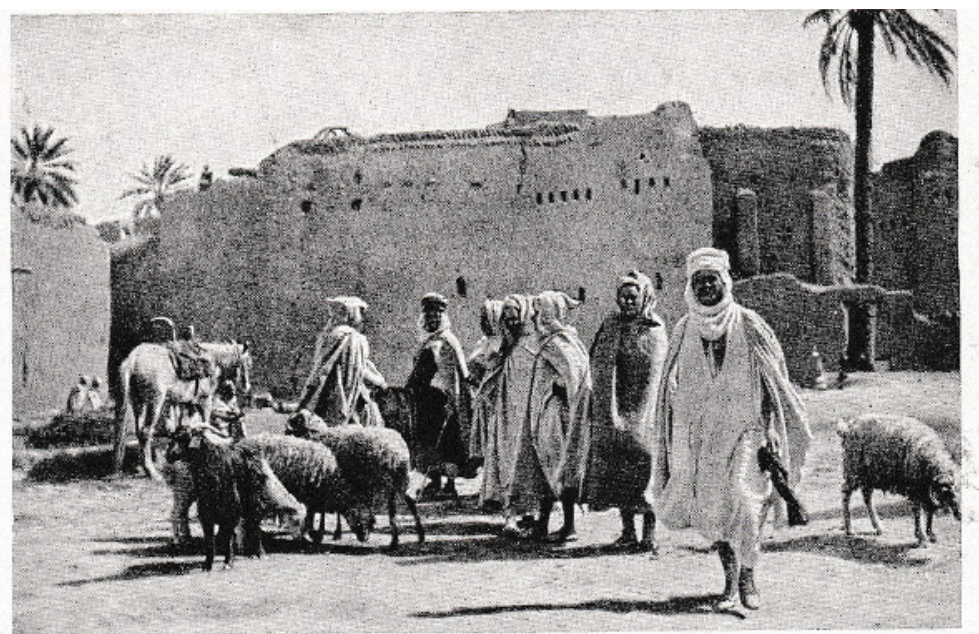

BY THE GOLDEN GATEWAY OF THE OLD SAHARAN PLUNDERERS

At Biskra, where these shepherds now peacefully tend their sheep, there is a break in the great rock wall of the Atlas. Through it Desert raiders used to pour, and through it from Roman days marched avenging forces. A source of gold it was also, when columns of slaves toiled wearily through it Photo, Miss C. Y. Huter

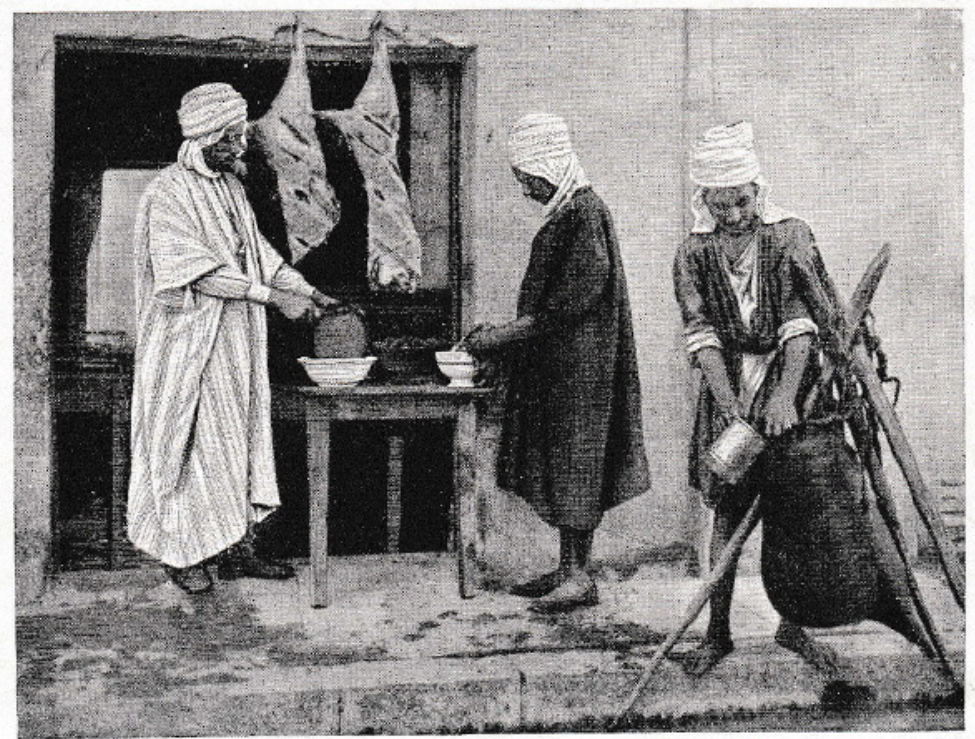

THE LAST REFUGE OF ROMAN ARTS OF COOKERY

It is an adventure to eat a meal in the spicy, smelly, native quarter. The Moorish cook is a It is an adventare the men who served Lucullus. His meat flavourings are sometimes fearful to remote descendant of the men who served Tuculus. Photo, Crete 


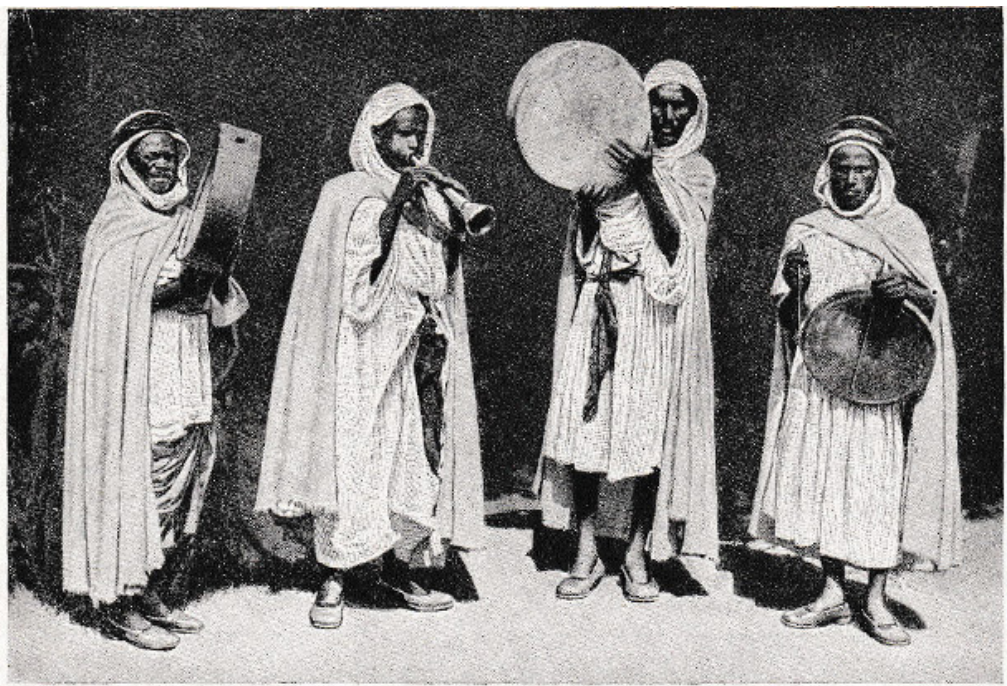

ONE BLACK FLUTE TO TWO BLACK TAMBOURINES AND A DRUM

The curious airs this flute-player can finger out of a few notes are not remarkable, but in the rhythms and cross-rhythms which the tambourine strummers and drummer weave as an accompaniment are

strange, wild effects of which syncopated Negro-American melodies are but faint, poor echoes

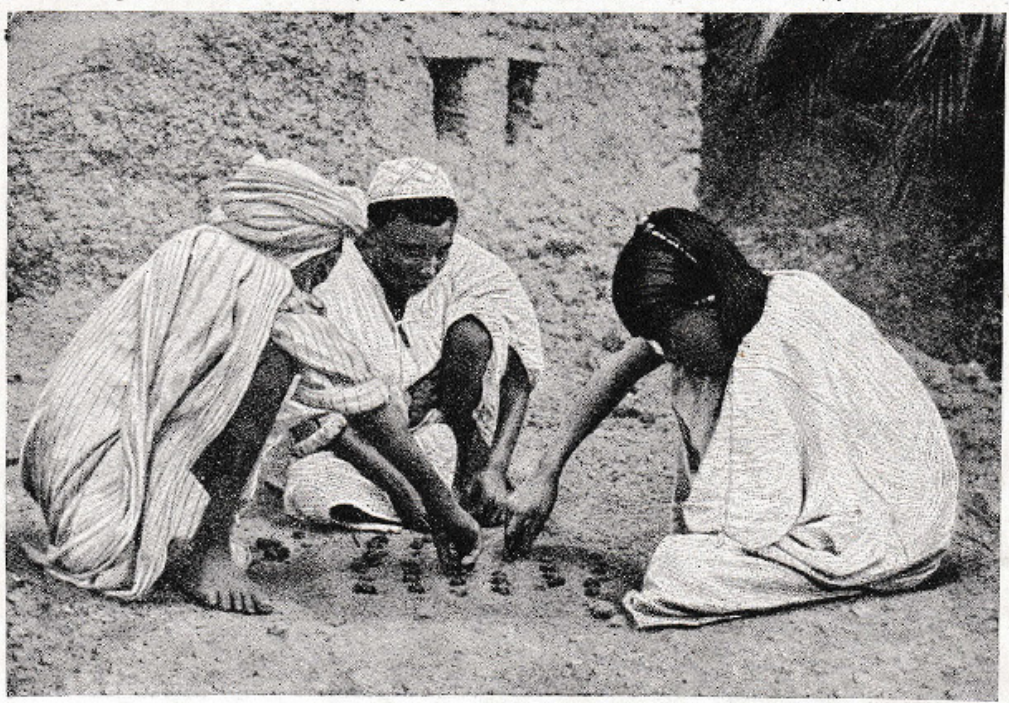

THE WAY THEY PLAY DRAUGHTS IN THE SAHARA

Arab boys of the Desert love checkerboard games with all the zest of their Saracen foretathers, but boards of morocco leather and pieces of ivory are only for sheikhs Even wood is so scarce in the Sahara that camel dung is used for fuel. So the young players draw their lines in the sand, and make their draughtsmen out of the fuel material

photos, Crett 


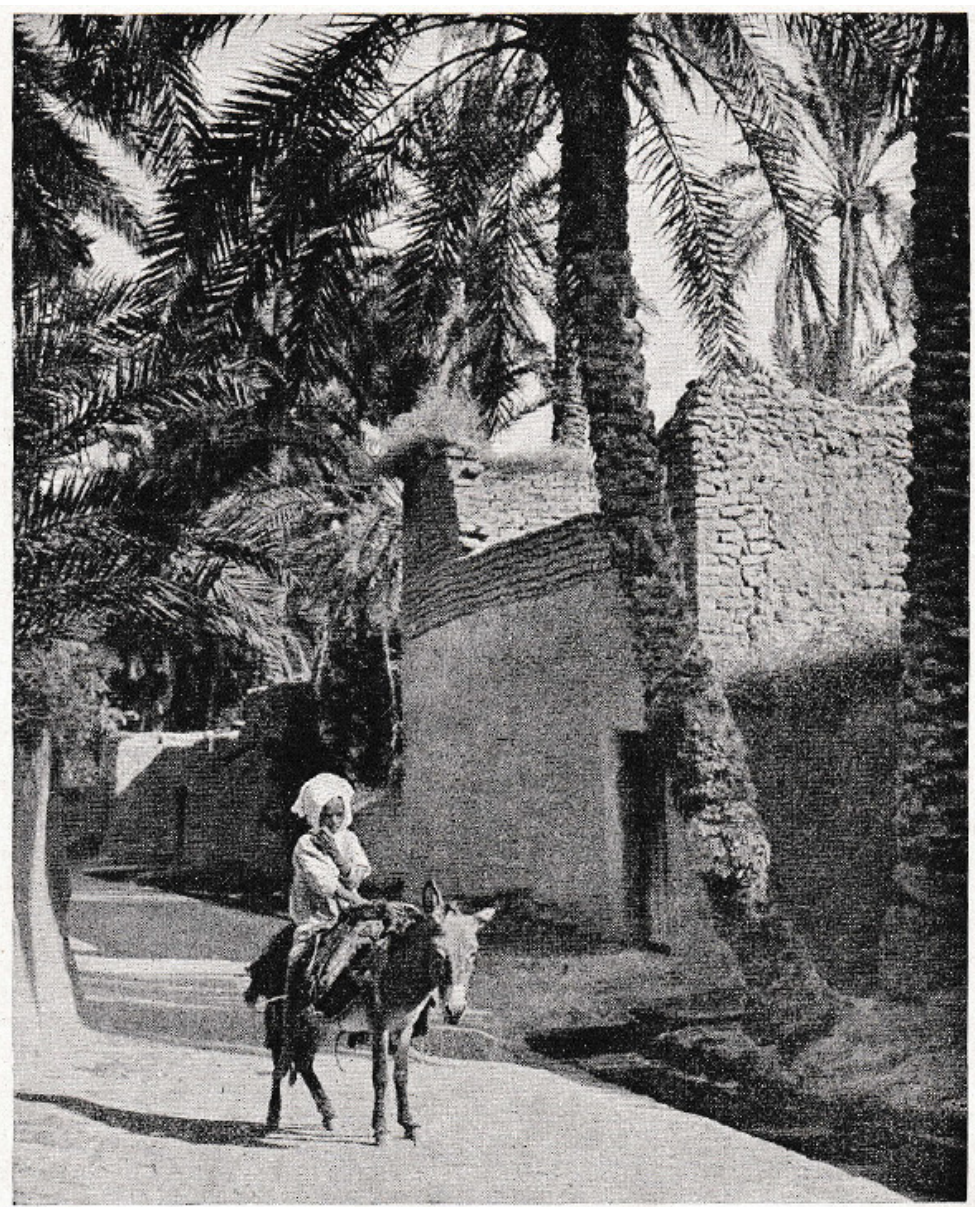

TRANSFORMING A ROCKY WASTE INTO A PALM-SHADED TOWN

When the French Army conquered Biskra it was a poor, mud-built hamlet set on the dry, stony fringe of the sands. Underground streams were found by digging, and now Biskra, with a quarter of a million date palms, lordly pleasure gardens, rich ficlds, railway, trams, cabs, and hotels like palaces, attracts the Sahara tripper from all parts of Europe

$$
\text { Pkoto, Donali MoLeisis }
$$

inhabitants have not been won over. There has been no fusion, no real union. The natives cherish their separatebeliefs, customs, instincts, antipathies. At heart they are the mortal enemies of Europe. Indeed, so far as any movement is discernible, it is in the contrary direction. The European element in
Algeria is becoming gradually Africanised. The African sun will not be denied. The streams of European colonisation are gradually absorbed into an African stock which is different from that of Europe in spirit, just as the snow-fed rivers from the Atlas sink into and are absorbed by the Desert sands. 


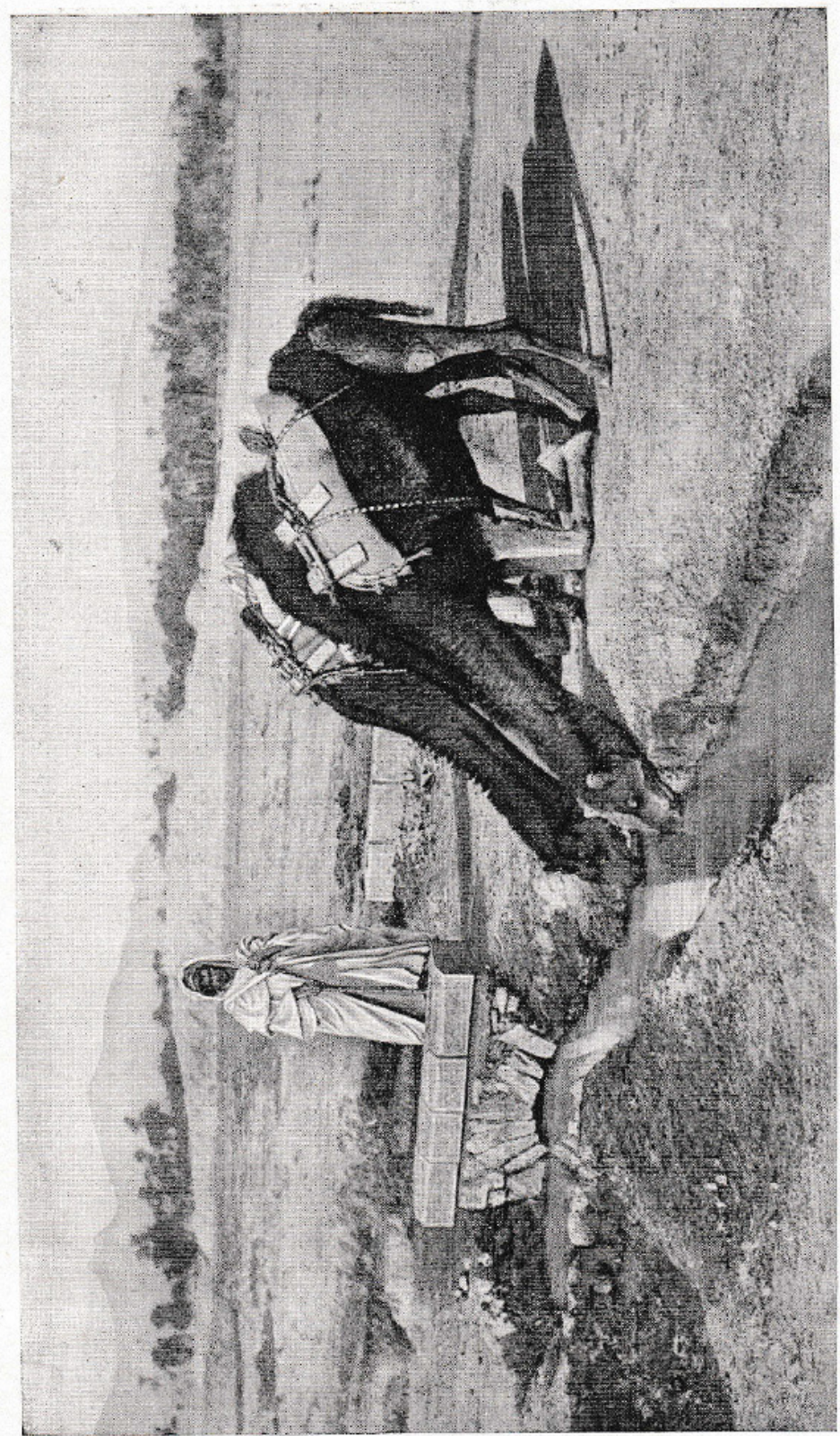

월

Z

동영

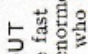

우용

占可器

3.

$\rightarrow \stackrel{f}{>}$

品骂总

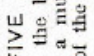

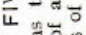

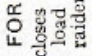

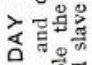

《卷亭蒙

o 5

这的跑

$\succ$ 해를

造的

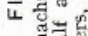

ㅇํㅇ हुำ

ํㅗㄹ

의웜

w

$\vdash$ 도융

过

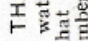

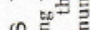

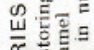

in

合

$\sum_{0} \Phi$

吅高

$\overrightarrow{0}$ б

送

콜롤 
